\title{
Composition of amino acids and related nitrogenous nutrients in feedstuffs for animal diets
}

\author{
Peng $\mathrm{Li}^{1} \cdot$ Guoyao $\mathrm{Wu}^{2}$ (D)
}

Received: 6 January 2020 / Accepted: 19 February 2020 / Published online: 11 March 2020

(c) The Author(s) 2020

\begin{abstract}
We analyzed the composition of amino acids (AAs) in oligopeptides, proteins, and the free pool, as well as creatine, agmatine, polyamines, carnosine, anserine, and glutathione, in animal- and plant-derived feedstuffs. Ingredients of animal origins were black soldier fly larvae meal (BSFM), chicken by-product meal, chicken visceral digest, feather meal, Menhaden fishmeal, Peruvian anchovy fishmeal, Southeast Asian fishmeal, spray-dried peptone from enzymes-treated porcine mucosal tissues, poultry by-product meal (pet-food grade), spray-dried poultry plasma, and spray-dried egg product. Ingredients of plant origins were algae spirulina meal, soybean meal, and soy protein concentrate. All animal-derived feedstuffs contained large amounts of all proteinogenic AAs (particularly glycine, proline, glutamate, leucine, lysine, and arginine) and key nonproteinogenic AAs (taurine and 4-hydroxyproline), as well as significant amounts of agmatine, polyamines, creatine, creatinine, creatine phosphate, and glutathione. These nitrogenous substances are essential to either DNA and protein syntheses in cells or energy metabolism in tissues (particularly the brain and skeletal muscle). Of note, chicken by-product meal, poultry by-product meal, and spray-dried poultry plasma contained large amounts of carnosine and anserine (potent antioxidants). Compared with most of the animal-derived feedstuffs, plant-derived feedstuffs contained much lower contents of glycine and proline, little 4-hydroxyproline, and no creatine, creatinine, creatine phosphate, carnosine or anserine. These results indicate the unique importance of animal-source feedstuffs in improving the feed efficiency, growth and health of animals (including fish and companion animals). Because soy protein concentrate is consumed by infants, children and adults, as are BSFM and algae for children and adults, our findings also have important implications for human nutrition.
\end{abstract}

Keywords Animal $\cdot$ Feeding $\cdot$ Nutrition $\cdot$ Peptides $\cdot$ Protein $\cdot$ Rendered products

$\begin{array}{ll}\text { Abbreviations } \\ \text { AA } & \text { Amino acid } \\ \text { BSFM } & \text { Black soldier fly larvae meal } \\ \text { CBPM } & \text { Chicken by-product meal } \\ \text { CVD } & \text { Chicken visceral digest } \\ \text { DM } & \text { Dry matter } \\ \text { EAA } & \text { Nutritionally essential amino acid }\end{array}$

Handling Editor: F. Blachier.

Electronic supplementary material The online version of this article (https://doi.org/10.1007/s00726-020-02833-4) contains supplementary material, which is available to authorized users.

Guoyao Wu

g-wu@tamu.edu

North American Renderers Association, Alexandria, VA 22314, USA

2 Department of Animal Science, Texas A\&M University, College Station, TX 77843, USA
FM-M Fishmeal (United States Menhaden)

FM-P Fishmeal (Peruvian anchovy)

FM-SE Fishmeal (Southeast Asian miscellaneous marine fishes)

HPLC High-performance liquid chromatography

Hyp 4-Hydroxyproline

NEAA Nutritionally nonessential amino acid

PCA Perchloric acid

PFG Pet-food grade

SBM Soybean meal

SDEP Spray-dried egg product

SDPM Spray-dried peptone from enzymes-treated porcine mucosal tissues

SDPP Spray-dried poultry plasma

SPC Soy protein concentrate 


\section{Introduction}

Animal-source feedstuffs are generally superior to plantsource ones for the growth and health of livestock, poultry, and fish (Wu 2018). This is due, in part, to the greater quantity of proteinogenic amino acids (AAs) and higher quality (the ratios and digestibilities of AAs) of the former than the latter. Traditionally, extensive research has focused on AAs that are not synthesized by animal cells and are known as nutritionally essential AAs (EAAs), including leucine, lysine, methionine, threonine, and tryptophan (Hou and Wu 2018a). However, little attention has been directed to AAs that are synthesizable in animal cells [so-called nutritionally nonessential AAs (NEAAs), such as glutamate, glutamine, glycine, proline, and 4-hydroxyproline] (e.g., Cummins et al. 2017; Dust et al. 2005; Myers et al. 2014). However, NEAAs have versatile nutritional and physiological functions and are generally more abundant in animal- than plant feedstuffs (Hou et al. 2015a). The high abundance of NEAAs in animal protein can cut the energetic and EAA costs of their de novo syntheses in animal cells and leads to improved feed efficiency in the production of animals, especially carnivorous species ( $\mathrm{Li}$ and $\mathrm{Wu} 2018$ ). In addition, animal-source feedstuffs contain taurine, creatine and creatine phosphate that are important anti-oxidants and participate in energy metabolism in tissues [particularly the brain, skeletal muscle, heart, and gonads of animals (Wu 2013)]. In contrast, plant-source feedstuffs lack these nitrogenous nutrients (Hou et al. 2019). Furthermore, animal-derived feedstuffs may contain polyamines that are essential for DNA and protein syntheses in mammals, birds, and other vertebrates (Kerr et al. 2017). Finally, the presence of oligopeptides [small peptides (containing 2-10 AA residues) and large peptides (containing 11-20 AA residues)] in animal-source feedstuffs may enhance their efficiency in promoting animal growth.

At present, little is known about the content of creatine, polyamines, and oligopeptides in animal-source feedstuffs, most of which are produced by the rendering and animal protein industries to convert wastes into high-quality protein sources, protect the global environment (Meeker and Hamilton 2006), and reduce carbon emissions from animal production (Wu 2018). In addition, the literature shows large variations of these substances and AAs in feedstuffs among different laboratories (e.g., Bryan 2018; Donadelli et al. 2019; Frikha et al. 2014; Kerr et al. 2017; Kim et al. 2000; Norberg et al. 2004; Renna et al. 2017; Shumo et al. 2019). These salient variations in published values might be attributable to the raw materials used (e.g., their sources, freshness and microbial contamination), processing technologies for ingredient production, and errors in
AA analyses. A database on the composition of AAs and related nutrients in a variety of protein ingredients derived from terrestrial animals and fishes is much needed to guide the formulation of diets for feeding livestock, poultry, fish, shrimp and companion animals (Turchini et al. 2019; Wu 2018). To achieve this goal, we analyzed eleven common animal-source feedstuffs and, for comparison, three common plant-source feedstuffs for AAs in oligopeptides, protein, and the free pool as well as creatine, creatine phosphate, creatinine, agmatine, polyamines, and glutathione.

\section{Materials and methods}

\section{Materials}

Chicken by-product meal (CBPM), chicken visceral digest (CVD), hydrolyzed feather meal, poultry by-product meal (pet-food grade), and spray-dried poultry plasma (SDPP) were obtained from North American Renderers Association (Alexandria, VA, USA). Black soldier fly larvae meal (BSFM) was manufactured by Dr. Jeffery Tomberlin (Department of Entomology, Texas A\&M University, College Station, TX, USA). Fishmeal (US Menhaden), fishmeal (Peruvian anchovy), and fishmeal (Southeast Asian miscellaneous marine fishes) were obtained from Tongwei Research Institute (Chengdu, China). Spray-dried peptone from enzymes-treated porcine mucosal tissues (SDPM; ProPep WD) was obtained from International Nutrition Inc. (Omaha, NE, USA). SDPM was a by-product of heparin extraction under salt solution and was dried by a spray-dried technology without the presence of plant protein carriers. Spray-dried egg product was obtained from IsoNova Technologies LLC (Springfield, MO, USA). Plant-source feedstuffs [algae spirulina meal, soybean meal (SBM), and soy protein concentrate (SPC)] were obtained from Aquaculture Research and Teaching Facility of Texas A\&M University (College Station, TX, USA).

High-performance liquid chromatography (HPLC)-grade water and methanol were purchased from Fisher Scientific (Houston, TX, USA). Balenine ( $\beta$-alanyl-3-methylhistidine; ophidine), which has been reported to be present in the skeletal muscles of snakes, whales and pigs (Boldyrev et al. 2013; Carnegie et al. 1982; Wolff et al. 1968), was a gift of Dr. J. Wolff (National Institute of Health, Bethesda, MD, USA). Other materials, including proteases, HPLC columns, AA standards, agmatine, carnosine ( $\beta$-alanyl-L-histidine), and anserine ( $\beta$-alanyl-1-methylhistidine) were products of Sigma Chemicals (St. Louis, MO, USA). 


\section{Chemical analyses}

Each food was finely ground to $0.5 \mathrm{~mm}$ in size before use for analysis. Dry matter (DM) content was determined by drying approximately $100 \mathrm{mg}$ samples to a constant mass in a $105^{\circ} \mathrm{C}$ oven. The content of crude protein, crude fat, ash (minerals), and carbohydrate in feedstuffs was determined as described by Wu et al. (2016a). Creatine and creatinine were analyzed by HPLC, as previously described by Kai et al. (1983). Creatine phosphate was converted into creatine by creatine kinase (Lamprecht and Stein 1965), followed by the HPLC analysis of creatine. The detection limits for creatine, creatinine and creatine phosphate were $3.5,3.5$, and $7 \mathrm{ng} / \mathrm{g}$ feed (as-fed basis), respectively.

For the determination of polyamines, agmatine, small peptides (carnosine, anserine and balenine), and free AAs, each feed sample $(\sim 200 \mathrm{mg})$ was homogenized in $2 \mathrm{ml}$ of $1.5 \mathrm{M} \mathrm{HClO}_{4}$ (perchloric acid, PCA). The homogenate was neutralized with $1 \mathrm{ml}$ of $2 \mathrm{M} \mathrm{K}_{2} \mathrm{CO}_{3}$, followed by addition of $2 \mathrm{ml}$ HPLC-grade water. The whole solution was centrifuged at $600 \mathrm{~g}$ for $10 \mathrm{~min}$, and the supernatant fluid was analyzed for polyamines and agmatine (Dai et al. 2014b), free AAs (Hou et al. 2019; Wu and Meininger 2008), carnosine and anserine (Wu et al. 2016a), and balenine (Hou et al. 2015b) using HPLC methods involving precolumn derivatization with $o$-phthaldialdehyde. Polyamines, agmatine, carnosine, anserine, balenine, and free AAs in samples were quantified on the basis of known amounts of standards using the Millenium-32 Software (Waters, Milford, MA, USA). The detection limits for carnosine, anserine and balenine were $0.35 \mathrm{ng} / \mathrm{g}$ feed (as-fed basis).

For determining peptide-bound plus free AAs (i.e., total AAs) in feeds (except for peptide-bound tryptophan), approximately $200 \mathrm{mg}$ samples were hydrolyzed in $10 \mathrm{~mL}$ of $6 \mathrm{~N} \mathrm{HCl}$ at $110{ }^{\circ} \mathrm{C}$ for $24 \mathrm{~h}$ under $\mathrm{N}_{2}$ (Dai et al. 2014a). For tryptophan analysis, approximately $100 \mathrm{mg}$ samples were hydrolyzed at $110{ }^{\circ} \mathrm{C}$ for $20 \mathrm{~h}$ in $10 \mathrm{~mL}$ of $4.2 \mathrm{M} \mathrm{NaOH}$ plus $0.1 \mathrm{~mL}$ of $25 \%$ thiodiglycol (an antioxidant), as previously described (Dai et al. 2014a). Free AAs were extracted from each feed as described previously for the determination of polyamines. The differences in AA content between the acid or alkaline hydrolysis and the free AA fraction were taken to indicate the content of peptide-bound AAs (i.e., AAs in proteins and small plus large peptides). The PCAsoluble fraction (containing small plus large peptides and free AA) was neutralized with $1 \mathrm{M} \mathrm{NaOH}$ and the supernatant fluid $(0.5 \mathrm{ml})$ was hydrolyzed in $10 \mathrm{~mL}$ of $6 \mathrm{~N} \mathrm{HCl}$ at $110{ }^{\circ} \mathrm{C}$ for $24 \mathrm{~h}$ under $\mathrm{N}_{2}$. The differences in AA content before and after the acid hydrolysis were used to calculate the content of small plus large peptides. Glutamine, glutamate, asparagine, and aspartate in the proteins and peptides of feedstuffs were determined using proteases after samples were dried in an oven $\left(105^{\circ} \mathrm{C}\right)$ for $20 \mathrm{~h}$, as we described previously (Hou et al. 2019; Li et al. 2011). Briefly, the working solution of enzymes contained the following per $1 \mathrm{ml}$ of phosphate-buffered saline ( $\mathrm{pH} 7.5$ ): $2 \mathrm{mg}$ pronase E (from Streptomyces griseus; Sigma Cat \#P5147), $2 \mathrm{mg}$ prolidase (from porcine kidney; Sigma Cat \#P6675), $2 \mathrm{mg}$ pyroglutamate aminopeptidase (from Bacillus amyloliquefaciens; Sigma Cat \#P4669), 2 mg carboxypeptidase A (from bovine pancreas; Sigma Cat \#C0261), and $2 \mathrm{mg}$ aminopeptidase M (from porcine kidney; Sigma Cat \#L0632). A finelygrounded feed sample $(\sim 50 \mathrm{mg})$ was incubated at $25{ }^{\circ} \mathrm{C}$ for $6 \mathrm{~h}$ with $250 \mu \mathrm{l}$ of phosphate-buffered saline ( $\mathrm{pH} 7.5)$ and $50 \mu \mathrm{l}$ of the enzyme solution. At the end of the incubation, $50 \mu \mathrm{l}$ of $1.5 \mathrm{M} \mathrm{HClO}_{4}$ was added to the solution, followed by the addition of $25 \mu \mathrm{l}$ of $2 \mathrm{M} \mathrm{K}_{2} \mathrm{CO}_{3}$ and $5 \mathrm{ml}$ of HLPC water. Blanks were prepared by adding $50 \mu \mathrm{l}$ of $1.5 \mathrm{M} \mathrm{HClO}_{4}$ to the assay mixture before the addition of $50 \mu$ of the enzyme solution. All analyses of AAs were performed in triplicate for each sample using HPLC methods involving precolumn derivatization with $o$-phthaldialdehyde (Dai et al. 2014a). Amino acids in samples were quantified on the basis of known amounts of standards (Sigma Chemicals, St. Louis, MO, USA) using the Waters Millenium-32 Software (Zhang et al. 2019). Peptide-bound AAs were calculated as total AAs minus free AAs. The content of true proteins plus peptides was calculated on the basis of the molecular weights of AA residues (i.e., the molecular weight of an intact AA-18; Hou et al. 2019).

\section{Statistical analysis}

Values (means \pm SEM) are expressed on the as-fed basis, because animal diets are generally formulated on this basis. Sample size $(n=6 /$ feed) was chosen on the basis of known variations of AAs among feeds ( $\mathrm{Li}$ et al. 2011) and statistical power calculation with a probability of 0.9 (Jobgen et al. 2008). Log transformation of variables was performed when the variance of data was not homogenous among treatment groups, as assessed by the Levene's test (Fu et al. 2010). Data on AA composition were analyzed by one-way analysis of variance and the Student-Newman-Keuls multiple comparison (Assaad et al. 2014). Probability values $<0.05$ were taken to indicate statistical significance.

\section{Results}

\section{Content of nutrients in animal- and plant-derived feedstuffs}

Results of the approximate analyses of nutrients in animaland plant-derived feedstuffs (as-fed basis) are summarized in (Table 1). The DM content of the feedstuffs varied from $88.7 \%$ for SDPM to $98.0 \%$ for chicken by-product meal. 
Table 1 Content of nutrients in animal- and plant-derived feedstuffs (\%, as-fed basis)

\begin{tabular}{|c|c|c|c|c|c|c|}
\hline Sample & Water & Dry matter & Crude protein & Crude fat & Minerals & Carbohydrates \\
\hline \multicolumn{7}{|c|}{ Animal-source feedstuffs } \\
\hline BSFM & $4.70 \pm 0.11^{\mathrm{h}}$ & $95.30 \pm 0.11^{\mathrm{e}}$ & $42.00 \pm 0.07^{\mathrm{m}}$ & $33.52 \pm 0.22^{\mathrm{b}}$ & $6.22 \pm 0.06^{\mathrm{i}}$ & $13.57 \pm 0.16^{\mathrm{d}}$ \\
\hline CBPM & $1.97 \pm 0.02^{1}$ & $98.03 \pm 0.02^{\mathrm{a}}$ & $68.07 \pm 0.11^{\mathrm{e}}$ & $13.38 \pm 0.05^{\mathrm{c}}$ & $12.38 \pm 0.17^{\mathrm{f}}$ & $4.20 \pm 0.11^{\mathrm{h}}$ \\
\hline CVD & $6.78 \pm 0.13^{\mathrm{f}}$ & $93.22 \pm 0.13^{\mathrm{g}}$ & $67.18 \pm 0.06^{\mathrm{g}}$ & $8.57 \pm 0.11^{\mathrm{e}}$ & $12.03 \pm 0.22^{\mathrm{f}}$ & $5.44 \pm 0.26^{\mathrm{g}}$ \\
\hline Feather meal & $4.20 \pm 0.03^{\mathrm{i}}$ & $95.80 \pm 0.03^{\mathrm{d}}$ & $91.27 \pm 0.03^{\mathrm{a}}$ & $3.52 \pm 0.02^{\mathrm{j}}$ & $0.87 \pm 0.01^{1}$ & $0.15 \pm 0.01^{1}$ \\
\hline FM-M & $7.23 \pm 0.05^{\mathrm{e}}$ & $92.77 \pm 0.05^{\mathrm{h}}$ & $62.40 \pm 0.07^{\mathrm{i}}$ & $11.13 \pm 0.08^{\mathrm{d}}$ & $18.86 \pm 0.03^{\mathrm{c}}$ & $0.38 \pm 0.02^{\mathrm{k}}$ \\
\hline FM-P & $8.41 \pm 0.05^{\mathrm{c}}$ & $91.59 \pm 0.05^{\mathrm{j}}$ & $68.77 \pm 0.10^{\mathrm{d}}$ & $7.32 \pm 0.03^{f}$ & $15.13 \pm 0.05^{\mathrm{e}}$ & $0.37 \pm 0.02^{j}$ \\
\hline FM-SE & $7.95 \pm 0.03^{\mathrm{d}}$ & $92.05 \pm 0.03^{\mathrm{i}}$ & $64.70 \pm 0.07^{\mathrm{h}}$ & $5.07 \pm 0.03^{\mathrm{g}}$ & $21.89 \pm 0.05^{\mathrm{a}}$ & $0.39 \pm 0.01^{\mathrm{j}}$ \\
\hline SDPM & $11.26 \pm 0.03^{\mathrm{a}}$ & $88.74 \pm 0.03^{1}$ & $55.18 \pm 0.06^{\mathrm{j}}$ & $4.63 \pm 0.07^{\mathrm{h}}$ & $19.78 \pm 0.24^{\mathrm{b}}$ & $9.14 \pm 0.18^{\mathrm{e}}$ \\
\hline PBM (PFG) & $3.19 \pm 0.08^{\mathrm{k}}$ & $96.81 \pm 0.08^{\mathrm{b}}$ & $70.20 \pm 0.10^{\mathrm{b}}$ & $11.50 \pm 0.07^{\mathrm{d}}$ & $11.20 \pm 0.06^{\mathrm{g}}$ & $3.91 \pm 0.15^{\mathrm{i}}$ \\
\hline SDPP & $4.58 \pm 0.03^{\mathrm{h}}$ & $95.42 \pm 0.03^{\mathrm{e}}$ & $69.77 \pm 0.06^{\mathrm{c}}$ & $4.02 \pm 0.09^{\mathrm{i}}$ & $18.28 \pm 0.05^{\mathrm{d}}$ & $3.35 \pm 0.08^{\mathrm{j}}$ \\
\hline SDEP & $4.87 \pm 0.05^{\mathrm{g}}$ & $95.13 \pm 0.05^{\mathrm{f}}$ & $48.90 \pm 0.05^{\mathrm{k}}$ & $35.01 \pm 0.07^{\mathrm{a}}$ & $4.88 \pm 0.03^{\mathrm{k}}$ & $6.34 \pm 0.13^{\mathrm{f}}$ \\
\hline \multicolumn{7}{|c|}{ Plant-source feedstuffs } \\
\hline Algae SM & $3.47 \pm 0.11^{\mathrm{j}}$ & $96.53 \pm 0.11^{\mathrm{c}}$ & $68.80 \pm 0.06^{\mathrm{d}}$ & $0.25 \pm 0.01^{\mathrm{m}}$ & $7.18 \pm 0.03^{h}$ & $20.30 \pm 0.12^{\mathrm{c}}$ \\
\hline SBM & $10.83 \pm 0.07^{\mathrm{b}}$ & $89.17 \pm 0.07^{\mathrm{k}}$ & $46.33 \pm 0.09^{1}$ & $0.94 \pm 0.02^{\mathrm{k}}$ & $5.68 \pm 0.03^{\mathrm{j}}$ & $36.22 \pm 0.07^{\mathrm{a}}$ \\
\hline SPC & $4.64 \pm 0.02^{\mathrm{h}}$ & $95.36 \pm 0.02^{\mathrm{e}}$ & $67.47 \pm 0.05^{\mathrm{f}}$ & $0.47 \pm 0.01^{1}$ & $5.53 \pm 0.04^{j}$ & $21.89 \pm 0.06^{\mathrm{b}}$ \\
\hline
\end{tabular}

Values are means $\pm \mathrm{SEM}, n=6$.

$B S F M$ black soldier fly larvae meal; $C B P M$ chicken by-product meal; $C V D$ chicken visceral digest; $F M-M$ fishmeal (United States Menhaden); $F M-P$ fishmeal (Peruvian anchovy); FM-SE fishmeal (Southeast Asian miscellaneous marine fishes); Hyp 4-hydroxyproline; $P B M$ (PFG) poultry by-product meal (pet-food grade); $P C A$ perchloric acid; SBM soybean meal; SDEP spray-dried egg product; SDPM spray-dried peptone from enzymes-treated porcine mucosal tissues; $S D P P$ spray-dried poultry plasma; $S M$ spirulina meal; $S P C$ soy protein concentrate.

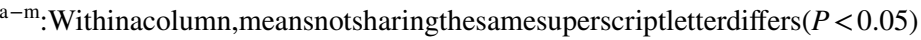

The content of crude protein was the highest in feather meal (91.3\%; $P<0.05)$ and the lowest in BSFM $(42.0 \% ; P<0.05)$. Spray-dried egg product had the highest content of crude fat (33.5\%; $P<0.05)$ but algae spirulina meal contained only $0.25 \%$ crude fat. The content of minerals was the highest in Southeast Asian fishmeal $(21.9 \% ; P<0.05)$, followed by SDPM, Menhaden fishmeal, spray-dried poultry plasma, Peruvian fishmeal, chicken visceral digest, and poultry byproduct meal (pet-food grade) in descending order. The content of carbohydrate was the highest in soybean meal $(36.2 \% ; P<0.05)$ and the lowest in feather meal $(0.15 \%$; $P<0.05)$.

\section{Content of total AAs, total free AAs, total peptides, and total proteins in feedstuffs}

Data on the content of total AAs (peptide-bound plus free AAs), total free AAs, total peptides, total small plus large peptides, and total proteins in feedstuffs are summarized in Table 2. Feather meal and BSFM contained the highest and lowest content of total AAs, respectively. Among animalsource feedstuffs, the content of total AAs was the secondhighest in spray-dried poultry plasma, followed by chicken visceral digest, Southeast Asian fishmeal, chicken by-product meal, and Peruvian fishmeal in descending order. Algae spirulina meal and soy protein concentrate also contained high content of total AAs, whereas soybean meal contained the lowest content of total AAs.

SDPM and spray-dried egg product contained the highest and lowest content of free AAs, respectively, which accounted for $39.4 \%$ and $0.37 \%$ of total AAs, respectively. The content of free AAs was the second-highest in chicken visceral digest ( $7.6 \%$ of total AAs), followed by Southeast Asian fishmeal (6.8\% of total AAs), Peruvian fishmeal (4.9\% of total AAs), BSFM (2.9\% of total AAs), and Menhaden fishmeal $(2.2 \%)$ in descending order. All the plant-source feedstuffs contained a low content of free AAs.

Feather meal and SDPM contained the highest and lowest content of peptide-bound AAs (i.e., AAs in proteins and small plus large peptides), respectively, which accounted for $99.5 \%$ and $60.6 \%$ of total AAs, respectively. The content of peptide-bound AAs was the second-highest in spray-dried poultry plasma $(85.4 \%)$, followed by chicken visceral digest (73.7\%), chicken by-product meal $(67.8 \%)$, Southeast Asian fishmeal (65.6\%), and Peruvian fishmeal $(63.3 \%)$ in descending order. The content of peptide-bound AAs accounted for $99.0 \%, 98.6 \%, 99.1 \%$, and $99.7 \%$ of total AAs in algae spirulina meal, soybean meal, and soy protein concentrate, respectively.

Chicken visceral digest and feather meal contained the highest and lowest content of AAs in PCA-soluble peptides (i.e., small plus large peptides), respectively, which accounted for $62.4 \%$ and $4.3 \%$ of AAs in total peptides, 
Table 2 Content of total amino acids, total free amino acids, total peptides, total small plus large peptides, total proteins, and total glutathione in animal- and plant-derived feedstuffs (as-fed basis) ${ }^{1}$

\begin{tabular}{|c|c|c|c|c|c|c|}
\hline \multirow[t]{3}{*}{ Sample } & \multirow{3}{*}{$\begin{array}{l}\text { Total amino acids ( } \mathrm{g} / \\
\mathrm{kg} \text { feed) } \\
\text { (A) }\end{array}$} & \multirow{3}{*}{$\begin{array}{l}\text { Total free amino acids } \\
\text { (g/kg feed) } \\
\text { (B) }\end{array}$} & \multicolumn{3}{|c|}{ Amino acids in peptides ( $\mathrm{g} / \mathrm{kg}$ feed $)$} & \multirow{3}{*}{$\begin{array}{l}\text { Total glutathione } \\
\text { (mg/kg feed) }\end{array}$} \\
\hline & & & Total & PCA-soluble peptides $^{2}$ & $\begin{array}{l}\text { PCA-insoluble } \\
\text { polypeptides }^{3}\end{array}$ & \\
\hline & & & $(\mathrm{C}=\mathrm{A}-\mathrm{B})$ & (D) & $(\mathrm{E}=\mathrm{C}-\mathrm{D})$ & \\
\hline \multicolumn{7}{|c|}{ Animal-source feedstuffs } \\
\hline BSFM & $503.8 \pm 1.5^{1}$ & $15.8 \pm 0.07^{\mathrm{e}}$ & $487.9 \pm 1.5^{\mathrm{j}}$ & $39.6 \pm 0.21^{\mathrm{j}}$ & $448.3 \pm 1.5^{\mathrm{k}}$ & $154 \pm 3.7^{c}$ \\
\hline CBPM & $685.6 \pm 2.4^{\mathrm{f}}$ & $7.28 \pm 0.05^{\mathrm{i}}$ & $678.3 \pm 2.4^{\mathrm{f}}$ & $96.2 \pm 0.44^{\mathrm{d}}$ & $582.1 \pm 2.6^{\mathrm{e}}$ & $113 \pm 4.8^{\mathrm{d}}$ \\
\hline CVD & $798.3 \pm 1.5^{\mathrm{c}}$ & $60.9 \pm 0.35^{b}$ & $737.4 \pm 1.4^{\mathrm{e}}$ & $459.0 \pm 1.6^{\mathrm{a}}$ & $278.4 \pm 1.9^{\mathrm{m}}$ & $19.8 \pm 0.6^{\mathrm{h}}$ \\
\hline Feather meal & $924.6 \pm 1.0^{\mathrm{a}}$ & $4.37 \pm 0.04^{j}$ & $920.3 \pm 1.0^{\mathrm{a}}$ & $39.1 \pm 0.15^{\mathrm{j}}$ & $881.2 \pm 1.1^{\mathrm{a}}$ & $0.71 \pm 0.02^{\mathrm{i}}$ \\
\hline FM-M & $601.8 \pm 0.7^{\mathrm{j}}$ & $13.2 \pm 0.08^{f}$ & $588.6 \pm 0.7^{\mathrm{i}}$ & $77.4 \pm 0.25^{\mathrm{e}}$ & $511.1 \pm 0.6^{\mathrm{j}}$ & $35.0 \pm 1.4^{\mathrm{f}}$ \\
\hline FM-P & $665.2 \pm 1.9^{\mathrm{g}}$ & $32.5 \pm 0.50^{\mathrm{d}}$ & $632.7 \pm 2.1^{\mathrm{h}}$ & $71.4 \pm 0.33^{\mathrm{f}}$ & $561.3 \pm 2.4^{\mathrm{g}}$ & $23.8 \pm 0.31^{\mathrm{g}}$ \\
\hline FM-SE & $703.6 \pm 1.0^{\mathrm{e}}$ & $48.1 \pm 0.32^{c}$ & $655.5 \pm 1.2^{\mathrm{g}}$ & $131.6 \pm 0.8^{\mathrm{c}}$ & $523.8 \pm 1.9^{\mathrm{i}}$ & $225 \pm 5.4^{\mathrm{a}}$ \\
\hline SDPM & $590.0 \pm 0.9^{\mathrm{k}}$ & $232.2 \pm 0.9^{\mathrm{a}}$ & $357.8 \pm 1.5^{1}$ & $180.1 \pm 0.6^{\mathrm{b}}$ & $177.7 \pm 2.0^{\mathrm{n}}$ & $175 \pm 3.2^{\mathrm{b}}$ \\
\hline PBM (PFG) & $642.0 \pm 1.4^{\mathrm{h}}$ & $14.7 \pm 0.08^{\mathrm{e}}$ & $627.3 \pm 1.4^{\mathrm{h}}$ & $78.7 \pm 0.52^{\mathrm{e}}$ & $548.6 \pm 1.3^{\mathrm{h}}$ & $73.2 \pm 1.6^{\mathrm{c}}$ \\
\hline SDPP & $864.0 \pm 3.3^{\mathrm{b}}$ & $10.3 \pm 0.09^{\mathrm{g}}$ & $853.7 \pm 3.3^{\mathrm{b}}$ & $49.7 \pm 0.41^{\mathrm{i}}$ & $804.0 \pm 3.1^{\mathrm{b}}$ & $48.0 \pm 1.3^{\mathrm{e}}$ \\
\hline SDEP & $630.1 \pm 0.6^{\mathrm{i}}$ & $2.35 \pm 0.01^{1}$ & $627.7 \pm 0.6^{\mathrm{h}}$ & $52.5 \pm 0.39^{\mathrm{h}}$ & $575.2 \pm 0.6^{\mathrm{f}}$ & $34.2 \pm 0.9^{f}$ \\
\hline \multicolumn{7}{|c|}{ Plant-source feedstuffs } \\
\hline Algae SM & $775.1 \pm 1.2^{\mathrm{d}}$ & $8.01 \pm 0.10^{\mathrm{h}}$ & $767.1 \pm 1.2^{\mathrm{d}}$ & $54.1 \pm 0.20^{\mathrm{g}}$ & $712.9 \pm 1.3^{\mathrm{d}}$ & $33.9 \pm 0.4^{\mathrm{f}}$ \\
\hline SBM & $443.9 \pm 1.2^{\mathrm{m}}$ & $4.25 \pm 0.04^{\mathrm{j}}$ & $439.7 \pm 1.2^{\mathrm{k}}$ & $32.3 \pm 0.10^{\mathrm{k}}$ & $407.4 \pm 1.2^{1}$ & $174 \pm 4.1^{b}$ \\
\hline SPC & $800.6 \pm 1.9^{c}$ & $2.81 \pm 0.02^{\mathrm{k}}$ & $797.8 \pm 1.9^{\mathrm{c}}$ & $21.9 \pm 0.10^{1}$ & $775.9 \pm 1.9^{\mathrm{c}}$ & $172 \pm 4.5^{\mathrm{b}}$ \\
\hline
\end{tabular}

$B S F M$ black soldier fly larvae meal; $C B P M$ chicken by-product meal; $C V D$ chicken visceral digest; $F M-M$ fishmeal (United States Menhaden); FM-P fishmeal (Peruvian anchovy); $F M$-SE fishmeal (Southeast Asian miscellaneous marine fishes); Hyp 4-hydroxyproline; $P B M$ ( $P F G$ ) poultry by-product meal (pet-food grade); $P C A$ perchloric acid; $S B M$ soybean meal; $S D E P$ spray-dried egg product; $S D P M$ spray-dried peptone from enzymes-treated porcine mucosal tissues; $S D P P$ spray-dried poultry plasma; $S M$ spirulina meal; $S P C$ soy protein concentrate

${ }^{1}$ Values are means \pm SEM, $n=6$. The amounts of amino acids were calculated on the basis of their intact molecular weights

${ }^{2}$ Small plus large peptides

${ }^{3}$ Proteins

${ }^{a-n}$ : Within a column, means not sharing the same superscript letter differs $(P<0.05)$

respectively. The content of AAs in PCA-soluble peptides was the second-highest in SDPM (50.3\% of total peptide-bound AAs), followed by Southeast Asian fishmeal (20.1\% of total peptide-bound AAs), chicken by-product meal ( $14.2 \%$ of total peptide-bound AAs), and Menhaden fishmeal (13.2\% of total peptide-bound AAs) in descending order. The content of AAs in PCA-soluble peptides accounted for $7.1 \%, 11.0 \%, 7.3 \%$, and $2.8 \%$ of total peptide-bound AAs in algae spirulina meal, soybean meal, and soy protein concentrate, respectively.

Feather meal and chicken visceral digest contained the highest and lowest content of AAs in PCA-insoluble polypeptides (i.e., proteins), respectively, which accounted for $95.7 \%$ and $37.83 \%$ of AAs in total peptides, respectively. The content of AAs in proteins was the secondhighest in spray-dried poultry plasma $(94.2 \%$ of total peptide-bound AAs), spray-dried egg product $(91.6 \%$ of total peptide-bound AAs), Peruvian fishmeal ( $88.7 \%$ of total peptide-bound AAs), and chicken by-product meal (85.8\% of total peptide-bound AAs) in descending order. The content of AAs in protein accounted for $92.9 \%, 89.0 \%$, $92.7 \%$, and $97.3 \%$ of total peptide-bound AAs in algae spirulina meal, soybean meal, and soy protein concentrate, respectively.

\section{Content of total individual AAs (peptide-bound plus free $A A s$ ) in feedstuffs}

Data on the content of total individual AAs (peptide-bound plus free AAs) in feedstuffs are summarized in Table 3. Tyrosine was the most abundant AA in the peptides plus the free AA pool in BSFM; glutamate in Menhaden fishmeal, Southeast Asian fishmeal, SDPM, and spray-dried egg product; glycine in chicken by-product meal, chicken visceral digest, and poultry by-product meal (pet-food grade); leucine in Peruvian fishmeal and spray-dried poultry plasma; 


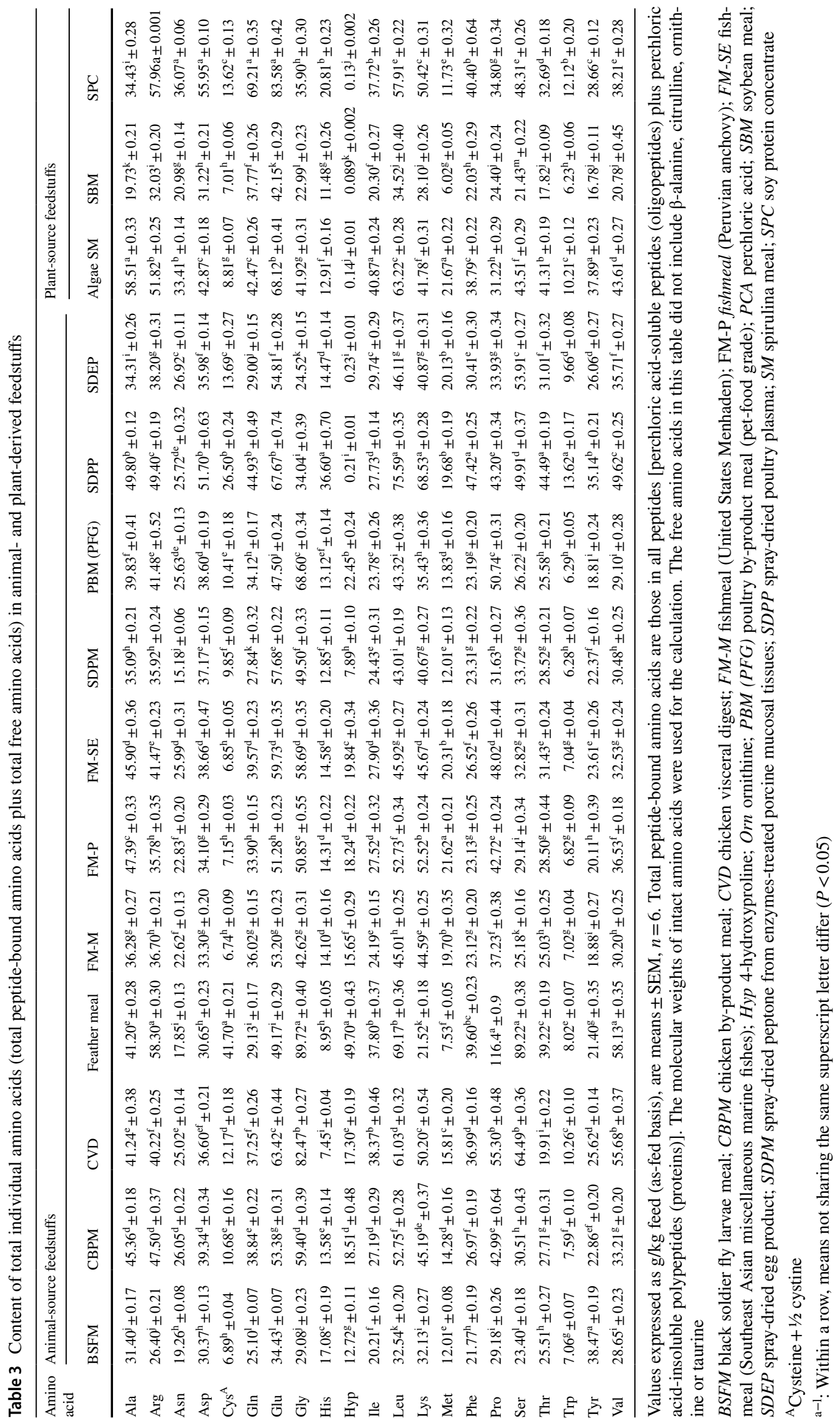


and proline in feather. Glutamate was the second most abundant AA in the peptides plus the free AA pool in BSFM and chicken by-product meal; glycine in feather meal, Southeast Asian fishmeal, and SDPM; leucine in Menhaden fishmeal; lysine in Peruvian fishmeal and spray-dried poultry plasma; and serine in chicken visceral digest, and spray-dried egg product. Glutamate was the third most abundant AA in the peptides plus the free AA pool in chicken visceral digest, Peruvian fishmeal, poultry by-product meal, and spray-dried poultry plasma; leucine in BSFM, chicken by-product meal, SDPM, and spray-dried egg product; lysine in Menhaden fishmeal; proline in Southeast Asian fishmeal; and serine in feather meal. Alanine was the fourth most abundant AA in the peptides plus the free AA pool in BSFM; arginine in chicken by-product meal; aspartate in spray-dried poultry plasma; glycine in Menhaden fishmeal and Peruvian fishmeal; leucine in chicken visceral digest, feather meal, Southeast Asian fishmeal, and poultry by-product meal; and lysine in SDPM and spray-dried egg product. In all animal-source feedstuffs except for BSFM and Southeast Asian fishmeal, tryptophan and cysteine were the least and second least abundant AA, respectively, but the opposite was true for BSFM and Southeast Asian fishmeal, whereas 4-hydroxyproline, histidine and methionine were among the third, fourth or fifth least abundant AAs depending on feedstuffs. Similar results were obtained when values were calculated as the percentage of total AAs in the feedstuffs (Supplemental Table 1).

Glutamate was the most abundant AA in the peptides plus the free AA pool in algae spirulina meal, soybean meal, and soy protein concentrate. In algae spirulina meal, leucine was the second most abundant $\mathrm{AA}$ in the peptides plus the free AA pool, followed by alanine, arginine, valine and serine in descending order. In both soybean meal and soy protein concentrate, glutamine was the second most abundant AA in the peptides plus the free AA pool, followed by either leucine or arginine as the third or fourth most abundant AA.

\section{Content of free AAs in feedstuffs}

Data on the Content of free AAs in feedstuffs are summarized in Table 4. The first, second, third, fourth, and fifth most abundant free AAs in descending order were as follows: tyrosine, glutamate, glutamine, leucine, and proline in BSFM; taurine, alanine, glycine, aspartate, and leucine in chicken by-product meal; leucine, serine, proline, alanine, and arginine in chicken visceral digest; cysteine, proline, alanine, leucine, and glutamate in feather meal; taurine, alanine, leucine, lysine, and glutamate in Menhaden fishmeal; taurine, histidine, alanine, leucine, and arginine in Peruvian fishmeal; taurine, alanine, leucine, valine, and proline in Southeast Asian fishmeal; leucine, lysine, alanine, valine, and aspartate in SDPM; taurine, alanine, glycine, glutamate, and aspartate in poultry by-product meal (pet-food grade); glutamate, taurine, alanine, arginine, and glycine in spraydried poultry plasma; and alanine, taurine, glutamate, arginine, and aspartate in spray-dried egg product.

Glutamate was the most abundant free AA in algae spirulina meal and arginine in both soybean meal and soy protein concentrate. Alanine was the second most abundant free AA in algae spirulina meal and glutamate in both soybean meal and soy protein concentrate. The content of other free AAs in plant-derived feedstuffs was very low, compared with animal-derived feedstuffs.

\section{Content of peptide-bound AAs in feedstuffs}

Data on the content of peptide-bound AAs (i.e., AAs in proteins plus small and large peptides) in feedstuffs are summarized in Table 5. Tyrosine was the most abundant peptide-bound AA in BSFM; glutamate in Menhaden fishmeal, SDPM, and spray-dried egg product; glycine in chicken by-product meal, chicken visceral digest, Southeast Asian fishmeal, and poultry by-product meal (pet-food grade); leucine in spray-dried poultry plasma; lysine in Peruvian fishmeal; and proline in feather. Glutamate was the second most abundant peptide-bound AA in BSFM, chicken by-product meal, Menhaden fishmeal, Southeast Asian fishmeal, and spray-dried egg product; glycine in feather meal and SDPM; leucine in Menhaden fishmeal, and Peruvian fishmeal; lysine in spray-dried poultry plasma; proline in poultry by-product meal (pet-food grade); and serine in chicken visceral digest and egg product. Lysine was the third most abundant peptide-bound AA in BSFM and Menhaden fishmeal; glutamine in SDPM; glutamate in chicken visceral digest, Peruvian fishmeal, SDPM, poultry by-product meal, and spray-dried poultry plasma; leucine in chicken by-product meal and egg product; lysine in BSFM and Menhaden fishmeal; proline in Southeast Asian fishmeal. Leucine was the fourth most abundant peptide-bound AA in BSFM, chicken visceral digest, and poultry by-product meal (pet-food grade); arginine in chicken by-product meal, feather meal, and SDPM; glycine in Menhaden fishmeal and Peruvian fishmeal; lysine in Southeast Asian fishmeal and egg product; and valine in spray-dried poultry plasma. In all animalsource feedstuffs except for BSFM and Menhaden fishmeal, tryptophan and cysteine were the least and second least abundant AA, respectively, but the opposite was true for BSFM and Menhaden fishmeal, whereas 4-hydroxyproline, histidine and methionine were among the third, fourth or fifth least abundant peptide-bound AAs depending on feedstuffs.

Leucine was the most abundant peptide-bound AA in algae spirulina meal and glutamate in soybean meal and soy 


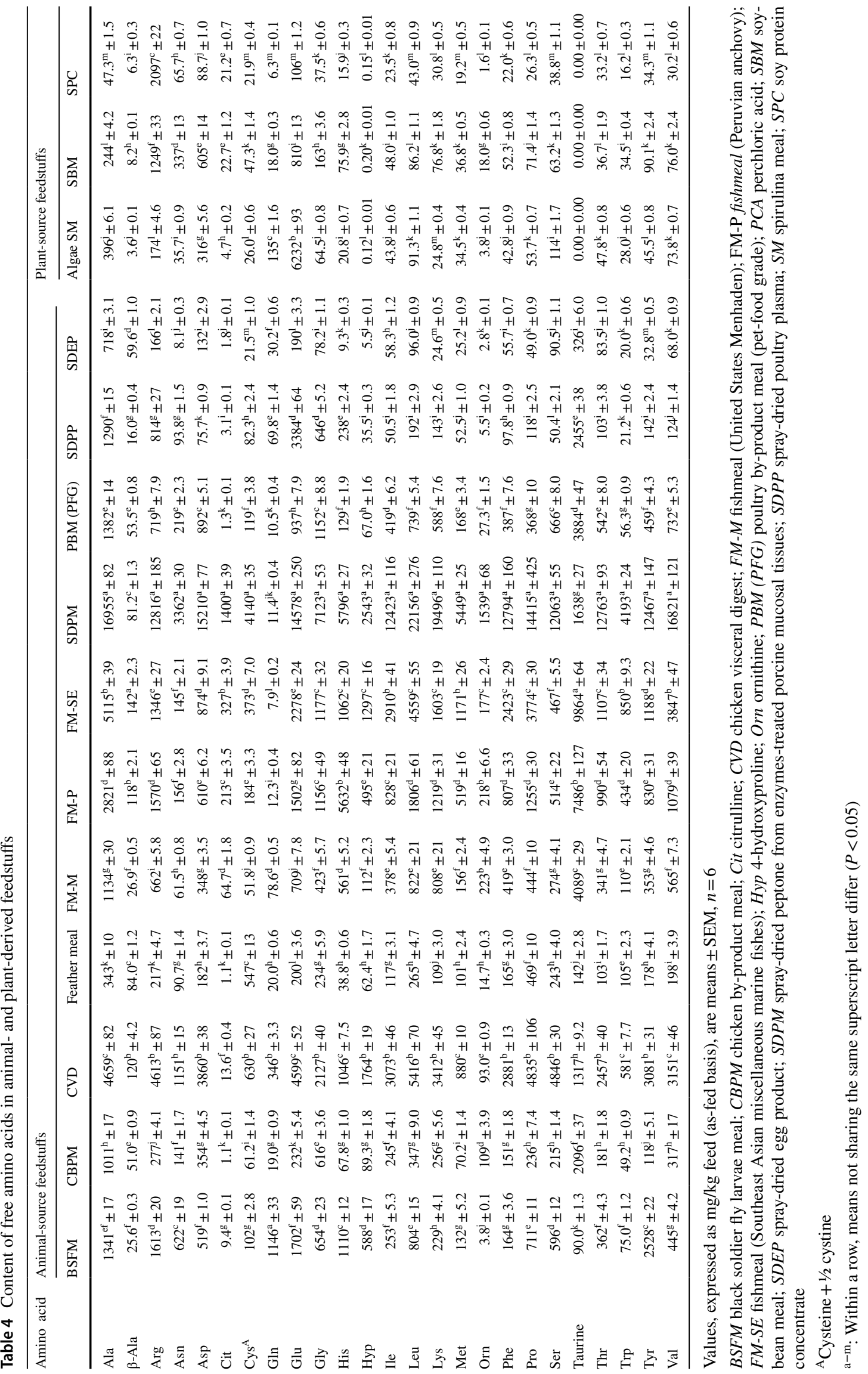




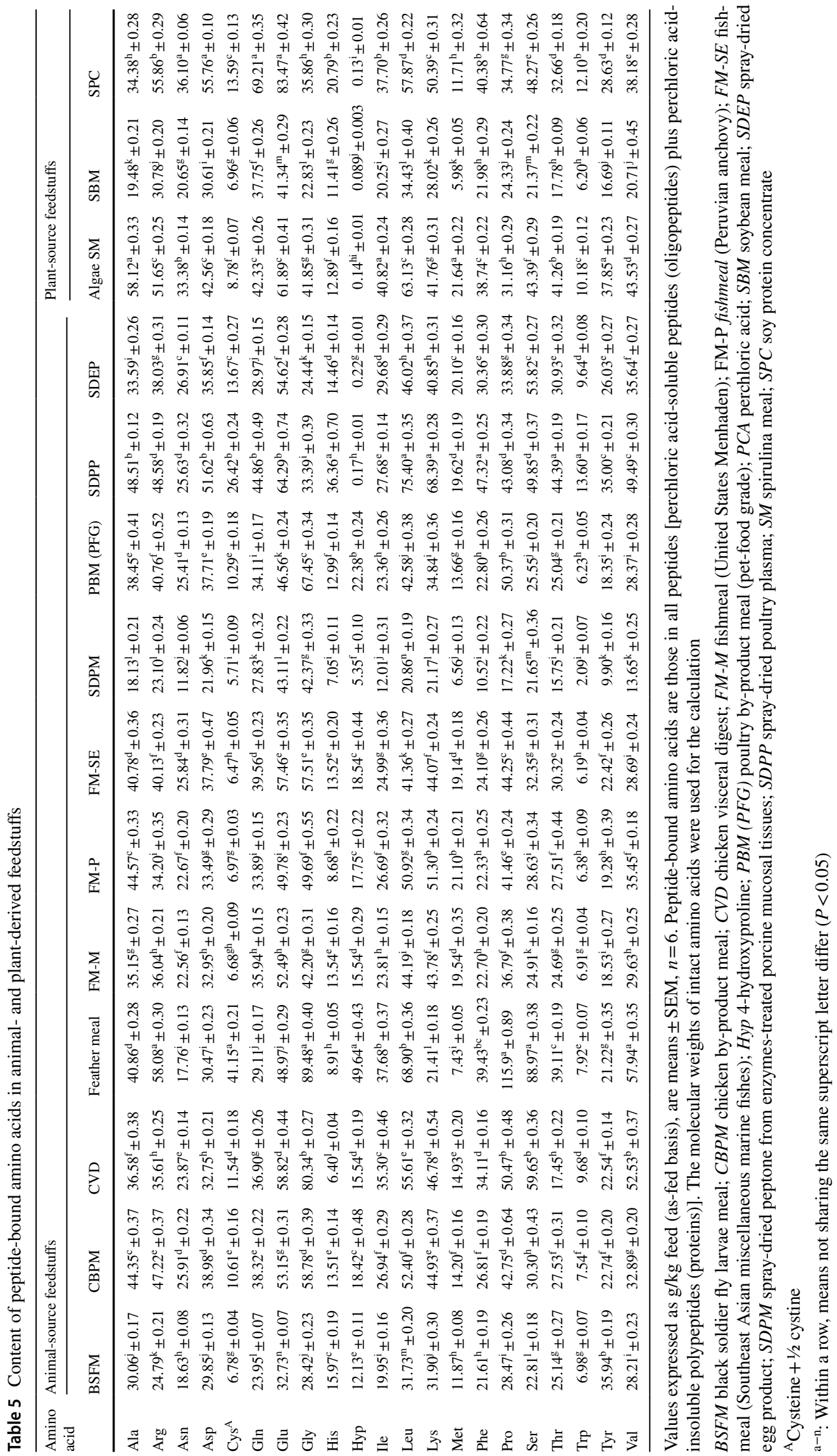


protein concentrate. In algae spirulina meal, glutamate was the second most abundant AA in their peptide-bound AA, followed by alanine, arginine, valine, serine, aspartate and glutamine in descending order. In both soybean meal and soy protein concentrate, glutamine was the second most abundant AA in their peptide-bound AA, followed by leucine, arginine, aspartate, and lysine in descending order.

\section{Content of AAs in the PCA-soluble peptides of feedstuffs}

Data on the content of AAs in the PCA-soluble peptides (i.e., AAs in small and large peptides called oligopeptides) of feedstuffs are summarized in Table 6 . The patterns of AAs in oligopeptides were very different from those in total peptides (i.e., oligopeptides plus proteins, Table 7). The most noticeable differences were that, in contrast to total peptides (oligo- plus poly-peptides), (a) phenylalanine and tyrosine were the first and second least abundant $\mathrm{AA}$ in the oligopeptides of BSFM; (b) the content of 4-hydroxyproline was greater than that of proline in the oligopeptides of chicken by-product meal; (c) 4-hydroxyproline was barely detectable in the oligopeptides of both spray-dried poultry plasma and egg product; (d) methionine was the least abundant AA in the oligopeptides of feather meal and SDPM and was the third least abundant AA in the oligopeptides of chicken visceral digest, father meal, Southeast Asian fishmeal, SDPM, poultry by-product meal (pet-food grade), and spray-dried poultry plasma; (e) histidine was the second least abundant AA in the oligopeptides of feather meal; and (f) methionine was the least abundant AA in the oligopeptides of soybean meal and soy protein concentrate and was the fourth least abundant proteinogenic AA in the oligopeptides of algae spirulina meal.

The PCA-soluble fraction in all of the animal-source feedstuffs contained various amounts of carnosine (Table 8). Except for the three fishmeal feedstuffs and BSFM, all of the analyzed animal-source feedstuffs contained various amounts of anserine (Table 8). Among the ten animalsource feedstuffs, the content of carnosine was the highest $(P<0.05)$ in chicken by-product meal, followed by spraydried poultry plasma, SDPM, Peruvian fishmeal, and poultry by-product meal (pet-food grade) in descending order. The content of anserine was the highest $(P<0.05)$ in chicken by-product meal, followed by poultry by-product meal (petfood grade), spray-dried poultry plasma, SDPM, and chicken visceral digest in descending order. Carnosine and anserine were absent from the plant-source feedstuffs (Table 8). All of the animal- and plant-source feedstuffs analyzed in the present study did not contain balenine.

Alanine was the most abundant AA in the oligopeptides of Menhaden fishmeal; glutamate in the oligopeptides of BSFM and SDPM; glycine in chicken by-product meal, chicken visceral digest, Peruvian fishmeal, Southeast Asian fishmeal, poultry by-product meal (pet-food grade), and egg product; and serine in feather meal and spray-dried poultry plasma. Glutamine was the second most abundant AA in the oligopeptides of BSFM; glutamate in the oligopeptides of chicken by-product meal, chicken visceral digest, Peruvian fishmeal, Southeast Asian fishmeal, poultry by-product meal (pet-food grade), and spray-dried poultry plasma; and glycine and proline in the oligopeptides of SDPM and feather meal, respectively. Glycine was the third most abundant AA in the oligopeptides of BSFM, feather meal and Menhaden fishmeal; serine in the oligopeptides of chicken visceral digest and Peruvian fishmeal; as well as alanine, arginine, glutamate, leucine, and proline in the oligopeptides of chicken by-product meal, poultry by-product meal (pet-food grade), egg product, spray-dried poultry plasma, and Southeast Asian fishmeal, respectively. Serine was the fourth most abundant AA in the oligopeptides of BSFM and Menhaden fishmeal; arginine in the oligopeptides of chicken by-product meal and feather meal; alanine in the oligopeptides of Peruvian fishmeal, Southeast Asian fishmeal, poultry by-product meal (pet-food grade), and spray-dried poultry plasma; leucine in the oligopeptides of chicken visceral digest and egg product; and aspartate in the oligopeptides of SDPM. In all animal-source feedstuffs except for Southeast Asian fishmeal and poultry by-product meal (pet-food grade), the content of tryptophan in the oligopeptides was lower $(P<0.05)$ than the content of cysteine, but the opposite was true for Southeast Asian fishmeal and poultry by-product meal (pet-food grade).

Glutamate was the most abundant AA in the oligopeptides of algae spirulina meal, and serine in the oligopeptides of soybean meal and soy protein concentrate. In algae spirulina meal, serine was the second most abundant AA in their oligopeptides, followed by aspartate, alanine, glutamine, threonine, asparagine, and leucine in descending order. In both soybean meal and soy protein concentrate, glutamate was the second most abundant AA in their oligopeptides, followed by glutamine, glycine, and aspartate in descending order.

\section{Content of AAs in the PCA-insoluble peptides of feedstuffs}

Data on the content of AAs in the PCA-insoluble polypeptides (i.e., proteins) of feedstuffs are summarized in Table 7. For all animal-source feedstuffs except for BSFM, chicken by-product meal, chicken visceral digest, and SDPM, the patterns of AA in proteins of the analyzed feedstuffs were generally similar to those in the total peptides (i.e., oligopeptides plus proteins, Table 7). Tyrosine was still the most abundant AA in the proteins of BSFM, lysine, leucine, alanine, and valine were the second, third, fourth, and fifth most 


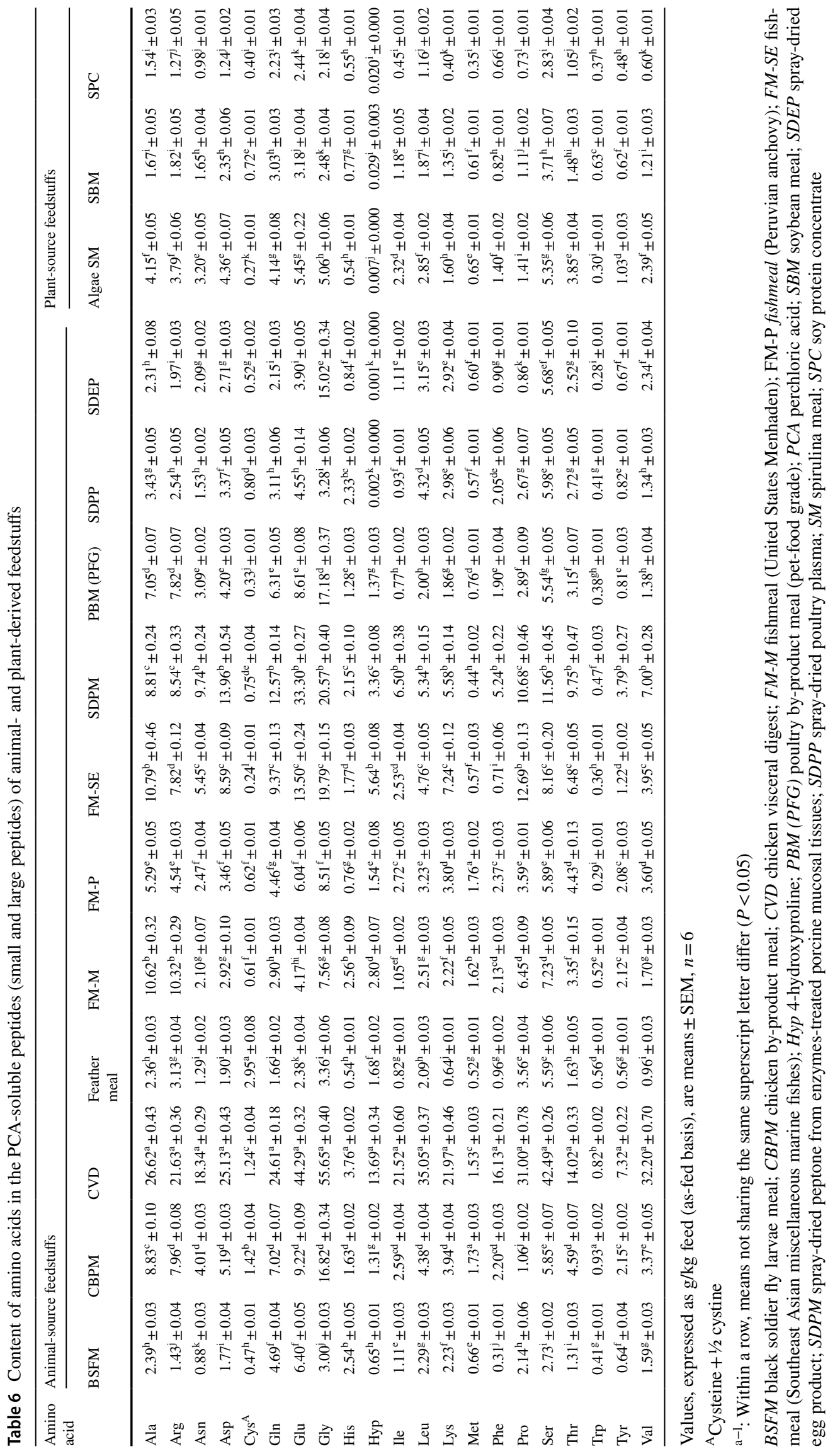




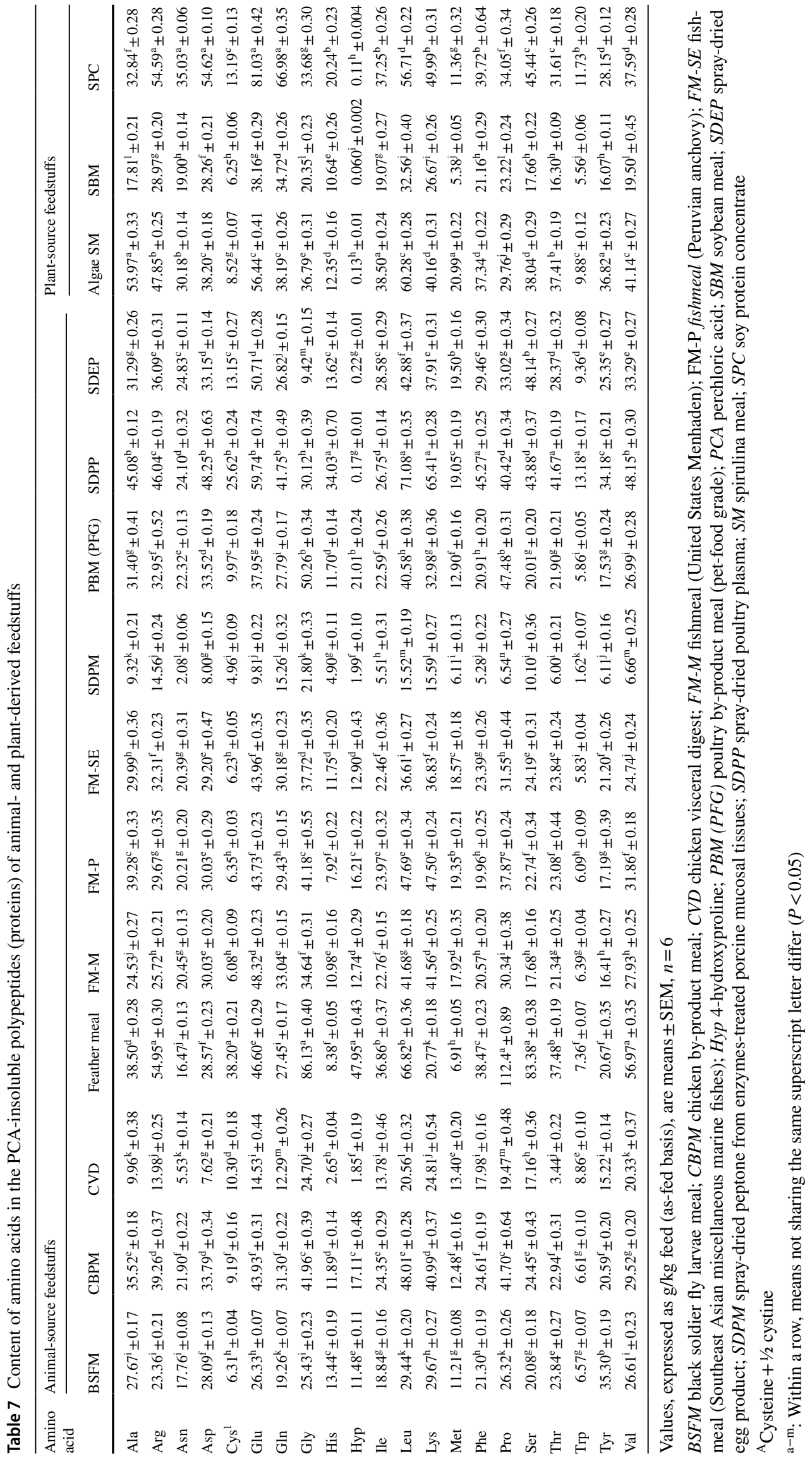


Table 8 Content of creatine, creatinine, creatine phosphate, carnosine, and anserine in animal- and plant-derived feedstuffs

\begin{tabular}{lllllll}
\hline Feedstuff & $\begin{array}{l}\text { Creatine } \\
(\mathrm{Cr})\end{array}$ & $\begin{array}{l}\text { Creatinine } \\
(\mathrm{CrT})\end{array}$ & $\begin{array}{l}\text { Cr phosphate } \\
(\mathrm{CrP})\end{array}$ & $\begin{array}{l}\text { Cr+CrT } \\
+\mathrm{CrP})\end{array}$ & Carnosine & Anserine \\
\hline Animal-source feedstuffs & & & & \\
BSFM & $3.5 \pm 0.06^{\mathrm{g}}$ & $178 \pm 2.8^{\mathrm{h}}$ & $226 \pm 4.1^{\mathrm{f}}$ & $408 \pm 6.0^{\mathrm{h}}$ & $127 \pm 4.5^{\mathrm{f}}$ & 0.00 \\
CBPM & $4.6 \pm 0.11^{\mathrm{f}}$ & $1447 \pm 46^{\mathrm{f}}$ & $90 \pm 1.9^{\mathrm{g}}$ & $1541 \pm 45^{\mathrm{g}}$ & $5506 \pm 40^{\mathrm{a}}$ & $7966 \pm 62^{\mathrm{a}}$ \\
CVD & $3.4 \pm 0.10^{\mathrm{g}}$ & $1056 \pm 54^{\mathrm{g}}$ & $601 \pm 15^{\mathrm{e}}$ & $1660 \pm 68^{\mathrm{f}}$ & $136 \pm 1.8^{\mathrm{f}}$ & $48.2 \pm 1.4^{\mathrm{e}}$ \\
Feather meal & $1.0 \pm 0.03^{\mathrm{h}}$ & $134 \pm 3.5^{\mathrm{i}}$ & $7.5 \pm 0.18^{\mathrm{h}}$ & $143 \pm 3.4^{\mathrm{j}}$ & $2.0 \pm 0.1^{\mathrm{h}}$ & $6.7 \pm 0.2^{\mathrm{f}}$ \\
FM-M & $59.2 \pm 1.0^{\mathrm{b}}$ & $3575 \pm 49^{\mathrm{c}}$ & $1751 \pm 30^{\mathrm{c}}$ & $5385 \pm 70^{\mathrm{c}}$ & $125 \pm 2.7^{\mathrm{f}}$ & 0.00 \\
FM-P & $127 \pm 2.9^{\mathrm{a}}$ & $5412 \pm 87^{\mathrm{a}}$ & $6150 \pm 116^{\mathrm{a}}$ & $11,689 \pm 198^{\mathrm{a}}$ & $665 \pm 17^{\mathrm{d}}$ & 0.00 \\
FM-SE & $14.0 \pm 0.35^{\mathrm{d}}$ & $4161 \pm 48^{\mathrm{b}}$ & $2403 \pm 54^{\mathrm{b}}$ & $6579 \pm 97^{\mathrm{b}}$ & $35.9 \pm 1.6^{\mathrm{g}}$ & 0.00 \\
SDPM & $42.1 \pm 1.2^{\mathrm{c}}$ & $2716 \pm 52^{\mathrm{d}}$ & $1430 \pm 47^{\mathrm{d}}$ & $4188 \pm 90^{\mathrm{d}}$ & $955 \pm 32^{\mathrm{c}}$ & $66.7 \pm 2.0^{\mathrm{d}}$ \\
PBM (PFG) & $3.5 \pm 0.07^{\mathrm{g}}$ & $1768 \pm 56^{\mathrm{e}}$ & $233 \pm 7.3^{\mathrm{f}}$ & $2005 \pm 59^{\mathrm{c}}$ & $545 \pm 15^{\mathrm{e}}$ & $1146 \pm 14^{\mathrm{b}}$ \\
SDPP & $3.3 \pm 0.10^{\mathrm{g}}$ & $44.0 \pm 0.9^{\mathrm{k}}$ & $92.0 \pm 2.0^{\mathrm{g}}$ & $139 \pm 2.8^{\mathrm{j}}$ & $1407 \pm 13^{\mathrm{b}}$ & $382 \pm 8.4^{\mathrm{c}}$ \\
SDEP & $7.0 \pm 0.13^{\mathrm{e}}$ & $102 \pm 2.8^{\mathrm{j}}$ & $87.8 \pm 3.1^{\mathrm{g}}$ & $196 \pm 5.8^{\mathrm{i}}$ & $1.8 \pm 0.16^{\mathrm{h}}$ & $6.5 \pm 0.4^{\mathrm{f}}$ \\
Plant-source feedstuffs & & & & & \\
Algae SM & 0.00 & 0.00 & 0.00 & 0.00 & 0.00 & 0.00 \\
SBM & 0.00 & 0.00 & 0.00 & 0.00 & 0.00 & 0.00 \\
SPC & 0.00 & 0.00 & 0.00 & 0.00 & 0.00 & 0.00 \\
\hline
\end{tabular}

Values, expressed as $\mathrm{mg} / \mathrm{kg}$ feed (as-fed basis), are means $\pm \mathrm{SEM}, n=6$

$B S F M$ black soldier fly larvae meal; $C B P M$ chicken by-product meal; $C V D$ chicken visceral digest; $F M$ $M$ fishmeal (United States Menhaden); FM-P fishmeal (Peruvian anchovy); $F M$-SE fishmeal (Southeast Asian miscellaneous marine fishes); Hyp 4-hydroxyproline; $P B M(P F G)$ poultry by-product meal (pet-food grade); $P C A$ perchloric acid; $S B M$ soybean meal; $S D E P$ spray-dried egg product; $S D P M$ spray-dried peptone from enzymes-treated porcine mucosal tissues; $S D P P$ spray-dried poultry plasma; $S M$ spirulina meal; $S P C$ soy protein concentrate

${ }^{\mathrm{a}-\mathrm{k}}$ Within a column, means not sharing the same superscript letter differ $(P<0.05)$ abundant AA in the proteins of this feedstuff, respectively. Leucine, glutamate, glycine, proline, and lysine were the first, second, third, fourth, and fifth most abundant AA in the proteins of chicken by-product meal, respectively. Lysine, glycine, leucine, valine and proline were the first, second, third, fourth, and fifth most abundant AA in the proteins of chicken visceral digest, respectively. Finally, glycine, lysine, leucine, glutamine, and arginine were the first, second, third, fourth, and fifth most abundant AA in the proteins of SDPM, respectively.

\section{Content of agmatine and polyamines in feedstuffs}

Data on the content of agmatine and polyamines in feedstuffs are summarized in Table 9. BSFM, chicken visceral digest. Per gram basis, Peruvian fishmeal, Southeast Asian fishmeal, and SDPM contained much greater $(P<0.05)$ amounts of agmatine than algae meal, soybean meal, and soy protein concentrate. For animal-source feedstuffs, the total content of polyamines was the highest $(P<0.05)$ in SDPM, followed by Peruvian fishmeal, Southeast Asian fishmeal, poultry byproduct meal, and chicken by-product meal in descending order.

\section{Content of creatine, creatinine, and creatine phosphate in feedstuffs}

Data on the content of creatine, creatinine, and creatine phosphate in feedstuffs are summarized in Table 8. For all animal-source feedstuffs tested, the content of creatine, creatinine, and creatine phosphate was the highest $(P<0.05)$ in Peruvian fishmeal. The content of creatinine was the second-highest in Southeast Asian fishmeal, followed by Menhaden fishmeal, SDPM, poultry by-product meal, chicken by-product meal, and chicken visceral digest, and BSFM in descending order. The content of creatine phosphate was the second-highest in Southeast Asian fishmeal, followed by Menhaden fishmeal, SDPM, chicken visceral digest, BSFM, and poultry by-product meal (pet-food grade) in descending order. The content of all creatine moieties was the highest $(P<0.05)$ in Peruvian fishmeal, followed by Menhaden fishmeal, Southeast Asian fishmeal, SDPM, and chicken visceral digest in descending order. Algae spirulina meal, soybean meal, and soy protein concentrate did not contain creatine, creatinine, or creatine phosphate. 
Table 9 Content of agmatine and polyamines in animal- and plant-derived feedstuffs

\begin{tabular}{|c|c|c|c|c|c|}
\hline Feedstuff & Agmatine & Spermidine & Spermine & Putrescine & Total PA \\
\hline \multicolumn{6}{|c|}{ Animal-source feedstuffs } \\
\hline BSFM & $615 \pm 16^{\mathrm{d}}$ & $127 \pm 5.7^{\mathrm{j}}$ & $33.7 \pm 0.9^{\mathrm{i}}$ & $20.2 \pm 1.0^{\mathrm{i}}$ & $181 \pm 6.3^{\mathrm{j}}$ \\
\hline СВРМ & $225 \pm 7.6^{\mathrm{f}}$ & $494 \pm 12^{\mathrm{e}}$ & $504 \pm 16^{\mathrm{d}}$ & $174 \pm 5.4^{\mathrm{c}}$ & $1172 \pm 15^{\mathrm{f}}$ \\
\hline CVD & $1727 \pm 40^{\mathrm{b}}$ & $384 \pm 12^{f}$ & $330 \pm 6.2^{f}$ & $161 \pm 6.7^{\mathrm{c}}$ & $875 \pm 17^{g}$ \\
\hline Feather meal & $118 \pm 5.4^{\mathrm{g}}$ & $775 \pm 14^{\mathrm{c}}$ & $310 \pm 9.3^{f}$ & $32.4 \pm 1.3^{\mathrm{h}}$ & $1117 \pm 18^{f}$ \\
\hline FM-M & $220 \pm 6.8^{f}$ & $21.1 \pm 0.7^{\mathrm{m}}$ & $133 \pm 5.5^{\mathrm{h}}$ & $97.6 \pm 5.2^{1}$ & $251 \pm 11^{\mathrm{i}}$ \\
\hline FM-P & $908 \pm 12^{c}$ & $232 \pm 13^{\mathrm{i}}$ & $1587 \pm 63^{\mathrm{a}}$ & $171 \pm 6.1^{\mathrm{c}}$ & $1990 \pm 76^{b}$ \\
\hline FM-SE & $1649 \pm 34^{\mathrm{b}}$ & $351 \pm 8.8^{g}$ & $210 \pm 6.2^{g}$ & $1074 \pm 18^{\mathrm{a}}$ & $1634 \pm 25^{\mathrm{c}}$ \\
\hline SDPM & $7027 \pm 108^{a}$ & $1361 \pm 74^{\mathrm{a}}$ & $1431 \pm 45^{\mathrm{b}}$ & $530 \pm 19^{b}$ & $3322 \pm 76^{\mathrm{a}}$ \\
\hline PBM (PFG) & $310 \pm 10^{\mathrm{e}}$ & $556 \pm 14^{\mathrm{d}}$ & $802 \pm 16^{c}$ & $66.2 \pm 2.0^{f}$ & $1423 \pm 27^{\mathrm{e}}$ \\
\hline SDPP & 0.00 & $17.1 \pm 0.7^{\mathrm{n}}$ & $16.1 \pm 0.8^{\mathrm{kl}}$ & $57.6 \pm 1.3^{\mathrm{g}}$ & $90.8 \pm 2.1^{\mathrm{k}}$ \\
\hline SDEP & 0.00 & $29.1 \pm 0.8^{1}$ & $18.0 \pm 0.9^{\mathrm{k}}$ & $143 \pm 4.4^{\mathrm{d}}$ & $190 \pm 4.2^{\mathrm{j}}$ \\
\hline \multicolumn{6}{|c|}{ Plant-source feedstuffs } \\
\hline Algae SM & $32.3 \pm 1.3^{\mathrm{i}}$ & $294 \pm 9.3^{\mathrm{h}}$ & $26.4 \pm 0.6^{\mathrm{j}}$ & $3.4 \pm 0.2^{\mathrm{k}}$ & $324 \pm 9.5^{\mathrm{h}}$ \\
\hline SBM & $303 \pm 6.7^{\mathrm{e}}$ & $1130 \pm 20^{\mathrm{b}}$ & $385 \pm 7.3^{\mathrm{e}}$ & $18.8 \pm 0.6^{\mathrm{i}}$ & $1533 \pm 22^{\mathrm{d}}$ \\
\hline SPC & $61.2 \pm 1.6^{\mathrm{h}}$ & $57.3 \pm 1.4^{\mathrm{k}}$ & $13.7 \pm 0.6^{1}$ & $8.8 \pm 0.3^{\mathrm{j}}$ & $79.8 \pm 1.4^{\mathrm{k}}$ \\
\hline
\end{tabular}

Values, expressed as $\mathrm{mg} / \mathrm{kg}$ feed (as-fed basis), are means $\pm \mathrm{SEM}, \mathrm{n}=6$

$B S F M$ black soldier fly larvae meal; $C B P M$ chicken by-product meal; $C V D$ chicken visceral digest; $F M$ $M$ fishmeal (United States Menhaden); FM-P fishmeal (Peruvian anchovy); FM-SE fishmeal (Southeast Asian miscellaneous marine fishes); Hyp 4-hydroxyproline; $P B M(P F G)$ poultry by-product meal (pet-food grade); $P C A$ perchloric acid; $S B M$ soybean meal; $S D E P$ spray-dried egg product; $S D P M$ spray-dried peptone from enzymes-treated porcine mucosal tissues; $S D P P$ spray-dried poultry plasma; $S M$ spirulina meal; $S P C$ soy protein concentrate

${ }^{a-n}$ Within a column, means not sharing the same superscript letter differ $(P<0.05)$

\section{Content of total glutathione in feedstuffs}

Data on the content of total glutathione in feedstuffs are summarized in Table 2. Among the analyzed animal-source feedstuffs, this tripeptide was most abundant in Southeast Asian fishmeal, followed by SDPM, BSFM, chicken by-product meal, poultry by-product meal (pet-food grade), spray-dried poultry plasma, and Menhaden fishmeal in descending order. The content of total glutathione in soybean meal and soy protein concentrate was similar to that in SDPM. Algae also contained a significant amount of glutathione.

\section{Discussion}

Adequate provision of AAs in diets is essential for the maximal growth and production performance as well as optimal health of all farm animals, including swine, poultry, ruminants, fish, and shrimp (Baker 2009; Li et al. 2007; Sulabo et al. 2013; Wu 2018; Yi et al. 2018; Zhang et al. 2015). Although AAs had long been classified as nutritionally essential or nonessential, the term "NEAA" has now been recognized as a misnomer in nutritional sciences (Hou and $\mathrm{Wu}$ 2017). Emerging findings have revealed the importance of NEAAs, such as glycine, proline, glutamate, glutamine and 4-hydroxyproline, in improving intestinal health and whole-body growth in animals (Fan et al. 2019; Le Floch et al. 2018; $\mathrm{Li}$ and $\mathrm{Wu}$ 2018; Wu et al. 2019). We have shown that glycine, proline and glutamate are the first, second, and third most abundant AAs in animal tissues, respectively (Wu 2013), supporting the notion that mammals, birds and other vertebrates have particularly high requirements for these nutrients (Hou and $\mathrm{Wu} 2018 \mathrm{~b}$; Liu et al. 2019; Meléndez-Hevia et al. 2009; Wu et al. 2014). Despite the immunological, nutritional and physiological importance of tryptophan, the content of this AA in feedstuffs was often not analyzed due to technical difficulties (e.g., Bryan 2018; Dozier et al. 2003; Jamdar and Harikumar 2008; Ravindran et al. 2005; Renna et al. 2017; Shumo et al. 2019). To our knowledge, this is the first report of all proteinogenic AAs, key nonproteinogenic AAs (taurine, $\beta$-alanine, ornithine, and citrulline), agmatine, polyamines, creatine, creatine phosphate, creatinine and glutathione in animal-source feedstuffs for guiding the formation of animal diets. Our findings are expected to shed light on the functionality of animal-derived feedstuffs in the production of farm animals, particularly carnivorous species.

Because of limited knowledge about AA biochemistry and nutrition, both researchers and animal producers had paid little attention to the content of NEAAs (peptide-bound plus free AAs) in feedstuffs, including animal-source feedstuffs produced by the rendering industry (e.g., Cummins 
et al. 2017; Dust et al. 2005; Myers et al. 2014). In studies that reported the content of some NEAAs in feedstuffs, no data were provided for glutamate, glutamine, aspartate or asparagine because the acid hydrolysis of the feedstuffs converted glutamine into glutamate and asparagine into aspartate. A recent study even showed that glutamate and glutamine were absent from proteins in the meal prepared from black soldier flies reared on chicken manure (Shumo et al. 2019). To our knowledge, this is the first detailed report of the high abundance of glutamine, glutamate, asparagine and aspartate in rendered animal feedstuffs (Tables 3-7). Our current work also provided much-needed data on glycine, proline, 4-hydrocyproline, and taurine in animal-source feedstuffs, the AAs that had often been ignored in most studies (e.g., Cummins et al. 2017; Dust et al. 2005; Klemesrud et al. 1997; Myers et al. 2014; Shumo et al. 2019; Supplemental Tables 2-5).

Published data on the content of NEAAs (peptide-bound plus free AAs) in feedstuffs showed exceedingly large variations by up to three magnitudes despite their similar content of DM or protein. For example, spray-dried egg product was reported to contain either $1.91 \mathrm{~g}$ glycine and $1.90 \mathrm{~g}$ proline per kg DM (Donadelli et al. 2019) or $16.4 \mathrm{~g}$ glycine and $16.7 \mathrm{~g}$ proline per kg DM (Norberg et al. 2004). Surprisingly, spray-dried inedible whole egg was found to contain only $0.02 \mathrm{~g}$ glycine/kg DM (Donadelli et al. 2019). We determined that spray-dried egg product contained $25.8 \mathrm{~g}$ glycine and $35.6 \mathrm{~g}$ proline per $\mathrm{kg}$ DM (Table 3 ). In addition, chicken by-product meal was reported to contain $6.07 \mathrm{~g}$ glycine, $4.13 \mathrm{~g}$ proline and $1.82 \mathrm{~g}$ 4-hydroxyproline per $\mathrm{kg} \mathrm{DM}$ (Donadelli et al. 2019), whereas poultry by-product meal was reported to contain $57 \mathrm{~g}$ glycine and $53 \mathrm{~g}$ proline per $\mathrm{kg}$ DM (Murray et al. 1997). We determined that chicken by-product meal contained $60.6 \mathrm{~g}$ glycine, $43.9 \mathrm{~g}$ proline and $18.9 \mathrm{~g}$ 4-hydroxyproline per kg DM and that poultry by-product meal contained $70.9 \mathrm{~g}$ glycine, $52.4 \mathrm{~g}$ proline and $23.2 \mathrm{~g}$ 4-hydroxyproline per kg DM (Table 3). Furthermore, BSFM was reported to contain $0.55 \mathrm{~g}$ cysteine and $23.2 \mathrm{~g}$ glycine per kg DM (Renna et al. 2017), $2.8 \mathrm{~g}$ cysteine and $19 \mathrm{~g}$ glycine per kg DM (Kawasaki et al. 2019), or $7.6 \mathrm{~g}$ cysteine and $29.2 \mathrm{~g}$ glycine per $\mathrm{kg}$ DM (Lei et al. 2019). In marked differences from porcine and poultry byproducts (Wu 2013), the content of 4-hydroxyproline in the meals from black soldier flies reared on chicken manure was reported to be 5.1 times that of proline (Shumo et al. 2019). We determined that BSFM contained $7.23 \mathrm{~g}$ cysteine, $30.5 \mathrm{~g}$ glycine, $30.6 \mathrm{~g}$ proline, and $13.4 \mathrm{~g}$ 4-hydroxyproline per $\mathrm{kg}$ DM (Table 3). A major difference in NEAAs between the animal- and plant-source feedstuffs analyzed in the present study is that the former contained a higher content of glycine and proline than the latter. These two NEAAs are nutritionally essential for the maximal growth and feed efficiency of poultry (Baker 2009), piglets (Wu et al. 2011), and fish
(Li et al. 2009). Additionally, 4-hydroxyproline, along with glycine (Fan et al. 2019), protects the intestine from oxidative stress (Wu et al. 2019) and enhance the growth performance of animals, including fish (Aksnes et al. 2008; Liu et al. 2014). This may explain, in part, why gut damage often occurs in animals such as pigs (Wu et al. 2014) and fish (Daniel 2018) that fed diets containing plant ingredients as the sole source of protein. The complete information on the content of all proteinoenic AAs and key nonproteinoenic AAs in animal-derived feedstuffs from the present study is very useful to guide the formulation of diets for animals.

Like NEAAs, the content of EAAs in animal-source feedstuffs also varied greatly in the published studies by up to tenfold or greater despite their similar content of DM or protein. For example, spray-dried egg product was reported to contain either $4.67 \mathrm{~g}$ leucine and $4.14 \mathrm{~g}$ lysine per $\mathrm{kg}$ DM (Donadelli et al. 2019) or $44.1 \mathrm{~g}$ leucine and $35.8 \mathrm{~g}$ lysine per kg DM (Norberg et al. 2004). We determined that spray-dried egg product contained $48.5 \mathrm{~g}$ leucine and $43.0 \mathrm{~g}$ lysine per kg DM (Table 3). In addition, chicken by-product meal was reported to contain either $5.10 \mathrm{~g}$ leucine and $4.59 \mathrm{~g}$ lysine per kg DM (Donadelli et al. 2019) or $44.9 \mathrm{~g}$ leucine and $40.6 \mathrm{~g}$ lysine per kg DM (Dust et al. 2005), whereas poultry by-product meal was reported to contain either $46 \mathrm{~g}$ leucine and $38 \mathrm{~g}$ lysine per $\mathrm{kg}$ DM (Murray et al. 1997), or $31.3 \mathrm{~g}$ leucine and $30.4 \mathrm{~g}$ lysine per kg DM (Dozier et al. 2003). We determined that the chicken by-product meal contained $53.9 \mathrm{~g}$ leucine and $46.1 \mathrm{~g}$ lysine $\mathrm{kg} \mathrm{DM}$ and that poultry by-product meal contained $44.7 \mathrm{~g}$ leucine and $36.6 \mathrm{~g}$ lysine per kg DM (Table 3). Furthermore, chicken visceral meal was reported to contain $12.5 \mathrm{~g}$ isoleucine and $15.0 \mathrm{~g}$ valine per $\mathrm{kg}$ DM (Djissou et al. 2018), $37 \mathrm{~g}$ isoleucine and $58 \mathrm{~g}$ valine per kg DM (Jamdar and Harikumar 2008), or $15 \mathrm{~g}$ isoleucine and $19 \mathrm{~g}$ valine per kg DM (Murray et al. 1997). It is unknown whether AA content in chicken visceral meal is affected by pre-mortem feeding. We determined that chicken viscera meal contained $41.2 \mathrm{~g}$ isoleucine and $59.7 \mathrm{~g}$ valine per kg DM (Table 3). Results of our work showed that leucine [an activator of the mechanistic target of rapamycin signaling to promote protein synthesis (Suryawan et al. 2020)] was the most abundant AA in all of the analyzed animal-source feedstuffs (Table 3), again underscoring their important roles in improving animal growth. Because the addition of animal-derived feedstuffs to a typical corn- and soybean meal-based diet improves the growth performance of the young pig (Hou et al. 2017; Wu 2018), their high content of leucine confers a nutritional benefit and does not result in an imbalance among dietary branched-chain AAs.

A novel observation from the present work is that tyrosine was the most abundant peptide-bound and free AA in BSFM (Tables 3 and 7). The content of tyrosine in BSFM was previously reported to be $23 \mathrm{~g} / \mathrm{kg}$ DM (Kawasaki et al. 2019) or not reported at all (Dumas et al. 2018; Spranghers 
et al. 2017). Interestingly, tyrosine is actively synthesized from phenylalanine and accumulated in insects for cuticle hardening and for defense against pathogens (Vavricka et al. 2014). As the precursor of melanin that determines the pigment of skin, BSFM may be particularly useful to maintain desirable colors in animals (e.g., fish, dogs and cats).

Peptide nutrition has received much attention in recent years because small and large peptides appear to have a greater rate of digestion and absorption in animals than intact proteins (Hou et al. 2017). To our knowledge, this is the first study to determine the content of AAs in the oligopeptides and proteins of animal-source feedstuffs. Except for chicken visceral meal and SDPM, all other animal-source feedstuffs contained more proteins than oligopeptides. Most AAs were present as oligopeptides in chicken visceral meal, whereas AAs were equally distributed between oligopeptides and proteins in SDPM (Table 2). In addition, a significant proportion of AAs existed as oligopeptides in Southeast Asian fishmeal, likely because proteases were used to prepare this feedstuff. For feedstuffs with a high proportion of oligopeptides, it is possible that their inclusion rates in animal diets can be reduced, as compared with feedstuffs with a high proportion of intact proteins. This can economically spare the use of high-quality protein sources as feed additives. Of particular note, chicken by-product meal and poultry by-product meal (pet-food grade) contained large amounts of carnosine and anserine (Table 8). Appreciable amounts of carnosine and anserine were also present in spray-dried poultry plasma [likely released from red blood cells (Ng and Marshall 1976)] and SDPM. The different amounts of carnosine in Menhaden, Peruvian and Southeast Asian fishmeals reflect the different sources of fish used to manufacture the feedstuffs (FAO 2018). For example, the skeletal muscle of 50-g largemouth bass contained carnosine $(43.6 \pm 0.91 \mathrm{mg} / \mathrm{kg}$ of wet tissue; mean $\pm \mathrm{SEM}, \mathrm{n}=6)$ but no detectable anserine (Wu G, unpublished data). Interestingly, all these three fishmeals did not contain a detectable amount of anserine, which is absent in humans and some animals including fishes (Boldyrev et al. 2013). Both carnosine and anserine are potent antioxidants (Boldyrev et al. 2013), their presence in the animal-source feedstuffs is expected to play an important role in protecting the small intestine from oxidative stress and inflammation, thereby improving intestinal health and function.

Both animals and plants contain agmatine, polyamines and glutathione (Baratella et al. 2018; Blachier et al. 2011; Lenis et al. 2018). There is little information about the content of these nitrogenous substances, creatine, creatine phosphate, creatinine, or glutathione in feedstuffs. Along with ornithine, agmatine is a precursor for the synthesis of polyamines in animal cells and plays a role in maintaining mitochondrial membrane permeability (Akasaka and Fujiwara 2019; Martinis et al. 2019). Bryan (2018) reported that the presence of significant amounts of agmatine $(\mathrm{mg} / \mathrm{kg}$ DM): fishmeal, 240; feather meal, 0.68; and soybean meal, 17.1. The values of agmatine content in the fishmeal used by Bryan (2018) were similar to those we found for Menhaden fishmeal but the values in feather meal and soybean meal were substantially lower than those we found for feather meal and soybean meal, which were 125 and $338 \mathrm{mg} / \mathrm{kg}$ DM, respectively (Table 9). To our knowledge, this is the first report of a greater abundance of agmatine in chicken visceral meal and SDPM than in other animal-source feedstuffs. Polyamines are substances are essential to DNA and protein syntheses in all cell types (Provenzano et al. 2019) and to energy metabolism in excitable tissues (the brain and skeletal muscle; Brosnan and Brosnan 2007). Bryan (2018) reported that the content of putrescine in fishmeal, feather meal and soybean meal was much greater than that of spermidine or spermine, but this was not observed for all the feedstuffs used in the present study except for Southeast Asian fishmeal and spray-dried egg product (Table 9). Of note, the content of spermidine (14-137 mg/kg DM) and spermine (12-72 mg/kg DM) reported by Kerr et al. (2017) for chicken by-product meal, feather meal and poultry byproduct meal was substantially lower than that we found for these types of feedstuffs (e.g., 500-804 mg spermidine $/ \mathrm{kg}$ DM and 324-826 mg spermine/kg DM; Table 9). Among all of the analyzed feedstuffs, SDPM contained the highest level of polyamines (Table 9), and this may explain, in part, a beneficial role for this ingredient in promoting the rapid recovery of the small intestine from weaning-induced injury (Hou et al. 2017). Furthermore, the content of total polyamines was greater in animal- than algae spirulina meal and soy protein concentrate (Table 9).

Creatine may be a functional nutrient in diets for livestock, poultry and fish (Wallimann et al. 2011). In contrast to plant-source feedstuffs, creatine, creatinine, and creatine phosphate were present in significant amounts in animalsource feedstuffs but were completely absent from all the plant-source feedstuffs (Table 8). These results indicate the unique importance of the former in improving the feed consumption, growth and health of animals (including companion animals). Furthermore, the simultaneous presence of a significant amount of glutathione [the major smallmolecular-weight antioxidant (Wu 2013)] with creatine and polyamines in animal-source feedstuffs protects the small intestine of animals from oxidative stress that often occurs under stressful conditions such as weaning, transportation, and heat stress (Wu 2018; Yang and Liao 2019). Finally, the inclusion of creatine in diets reduces the need for its endogenous synthesis of arginine, glycine and methionine due to a potent inhibition of renal arginine:glycine amidinotransferase expression (Brosnan and Brosnan 2007), thereby sparing these AAs for protein synthesis. In livestock, poultry and fish that are fed creatine-free diets, large amounts of 
arginine, glycine and methionine must be utilized for producing creatine, which is highly abundant in skeletal muscle. For example, in young (Wu et al. 2016b) and gestating (Wu et al. 2018) swine, creatine synthesis accounts for about $20 \%$ and 50\%, respectively, of arginine catabolized in the body. There is also evidence that dietary supplementation with creatine to growing-finishing (Maddock et al. 2002; Young et al. 2007) and gestating (Vallet et al. 2013) swine improves their growth and reproductive performances. Collectively, these results indicate the unique importance of creatine in animal-source feedstuffs in improving the feed consumption, growth, health and reproduction of animals (including farm, companion and aquatic animals). Our findings will also guide the cost-effective formulation of new diets for livestock, poultry, fish and shrimp (e.g., reducing the use of fishmeal in aquafeeds) that is based on the nutrient composition and complementarity of feedstuffs, an important area of animal nutrition research (Le Floch et al. 2018; Turchini et al. 2019; Wu 2018).

Results of this study may have important implications for human nutrition. Soybean proteins have been consumed by humans for centuries in a variety of forms, including infant formulas, flours, protein isolates and concentrates, and textured components (Friedman and Brandon 2001; Singh et al. 2008). This food is popular for infants, children and adults who are allergic to cow's milk protein. The content of most AAs was similar between SPC and egg (Table 3). Notably, the content of methionine in SPC ( $\mathrm{g} / \mathrm{kg}$ food) was relatively low (Gorissen et al. 2018) and was only 58\% of that in eggs (Table 3). Complementary intake of animal-source protein [e.g., meat (Wu et al. 2016a) and egg] can prevent a deficiency of methionine in soy product-based diets. Likewise, algae has been part of human diets for thousands of years in many regions of the world, including Asia, Europe, South America, and North America (Wells et al. 2017). Global demands for algae as a functional food are growing due to its health benefits (Koyande et al. 2019). However, algae contained 36\% less cysteine than eggs (Table 3), and this should be brought into the attention of nutritionists. Finally, insects (including black soldier fly larvae) have been used as human foods in more than 110 countries all over the world (MacEvilly 2000) and at least 2,000 insect species are considered to be edible in human diets (Jongema 2012). Edible insects provide high-quality animal protein, with their nutritional quality likely depending on their species and developmental stage (egg, larvae, pupae and adult; Roos 2018; Rumpold and Schlüter 2013). Interestingly, BSFM contained $48 \%$ more tyrosine than eggs (Table 3 ). Thus, under various environmental and psychological stresses, ingestion of insect proteins may be a lost-cost source of tyrosine for the syntheses of dopamine and norepinephrine in the brain to improve the adaptation, cognitive performance, and neurological function of humans (Lieherman 1994; Wurtman et al.
1981). This may also be applied to farm animals when they are faced with a variety of stress factors, such as weaning, lactation, pregnancy, and exposure to low temperatures.

In conclusion, we analyzed all peptide-bound and free AAs, as well as agmatine, polyamines, creatine, carnosine, anserine, and glutathione, in animal- and plant-source feedstuffs. Compared with plant-source feedstuffs, most of the animal-source feedstuffs contained much larger amounts of glycine, proline and 4-hydroxyproline. All feedstuffs contained significant amounts of agmatine, polyamines, and glutathione. Chicken by-product meal, poultry by-product meal, and spray-dried poultry plasma contained large amounts of carnosine and anserine. In contrast, taurine, creatine, creatinine, and creatine phosphate were present in significant amounts in all animal-derived feedstuffs but were absent from plant-derived feedstuffs. These results indicate the unique importance of animal-source feedstuffs in improving the feed efficiency, growth and health of animals (including companion and aquatic animals). Because soy protein concentrate is consumed by infants, children and adults, as are BSFM and algae for children and adults, our findings also have important implications for human nutrition.

Acknowledgements This work was supported by Texas A\&M AgriLife Research (H-8200). We thank Dr. Gayan I. Nawaratna and Mr. Wenliang He for technical assistance, as well as Drs. Jeffery Tomberlin, Delbert M. Gatlin III, and Heifeng Mi for help with feedstuff collection for this study.

\section{Compliance with ethical standards}

Conflict of interest The authors declare that they have no conflict of interest.

Ethical statement This study involved the chemical analyses of animalsource and plant-source feedstuffs. No approval of animal use protocols was required.

Informed consent No informed consent is required for this study.

Open Access This article is licensed under a Creative Commons Attribution 4.0 International License, which permits use, sharing, adaptation, distribution and reproduction in any medium or format, as long as you give appropriate credit to the original author(s) and the source, provide a link to the Creative Commons licence, and indicate if changes were made. The images or other third party material in this article are included in the article's Creative Commons licence, unless indicated otherwise in a credit line to the material. If material is not included in the article's Creative Commons licence and your intended use is not permitted by statutory regulation or exceeds the permitted use, you will need to obtain permission directly from the copyright holder. To view a copy of this licence, visit http://creativecommons.org/licenses/by/4.0/. 


\section{References}

Akasaka N, Fujiwara S (2019) The therapeutic and nutraceutical potential of agmatine, and its enhanced production using Aspergillus oryzae. Amino Acids 52: 181-197

Aksnes A, Mundheim H, Toppe J, Albrektsen S (2008) The effect of dietary hydroxyproline supplementation on salmon (Salmo salar L.) fed high plant protein diets. Aquaculture 275:242-249

Assaad H, Zhou L, Carroll RJ, Wu G (2014) Rapid publication-ready MS-Word tables for one-way ANOVA. SpringerPlus 3:474

Baker DH (2009) Advances in protein-amino acid nutrition of poultry. Amino Acids 37:29-41

Baratella D, Bonaiuto E, Magro M et al (2018) Endogenous and foodderived polyamines: determination by electrochemical sensing. Amino Acids 50:1187-1203

Blachier F, Davila AM, Benamouzig R, Tome D (2011) Channelling of arginine in $\mathrm{NO}$ and polyamine pathways in colonocytes and consequences. Front Biosci 16:1331-1343

Boldyrev AA, Aldini G, Derave W (2013) Physiology and pathophysiology of carnosine. Physiol Rev 93:1803-1845

Brosnan JT, Brosnan ME (2007) Creatine: endogenous metabolite, dietary, and therapeutic supplement. Annu Rev Nutr 27:241-261

Bryan DDSL (2018) Characterization of protein sources and their effects on broiler performance, digestive tract morphology and caecal fermentation metabolites. Dissertation, University of Saskatchewan, Saskatoon, Canada

Carnegie PR, Hee KP, Bell AW (1982) Ophidine ( $\beta$-alanyl-L-3methylhistidine, 'Balenine') and other histidine dipeptides in pig muscles and tinned hams. J Sci Food Agric. 33:795-801

Cummins VC, Rawles SD, Thompson KR et al (2017) Evaluation of black soldier fly (Hermetia illucens) larvaemeal as partial or total replacement of marine fish meal in practical diets for Pacific white shrimp (Litopenaeus vannamei). Aquaculture 473:337-344

Dai ZL, Wu ZL, Jia SC, Wu G (2014a) Analysis of amino acid composition in proteins of animal tissues and foods as pre-column $o$-phthaldialdehyde derivatives by HPLC with fluorescence detection. J Chromatogr B 964:116-127

Dai ZL, Wu ZL, Wang JJ et al (2014b) Analysis of polyamines in biological samples by HPLC involving pre-column derivatization with $o$-phthalaldehyde and $N$-acetyl-L-cysteine. Amino Acids 46:1557-1564

Daniel N (2018) A review on replacing fish meal in aqua feeds using plant protein sources. Int J Fisheries Aquatic Studies 6:164-179

Djissou ASM, Odjo I, Godome T et al (2018) Amino acids composition of maggot, earthworm, termite and chicken viscera meals used as proteins sources in fish feeding. Int J Aquaculture 8:114-118

Donadelli RA, Aldrich CG, Jones CK, Beyer RS (2019) The amino acid composition and protein quality of various egg, poultry meal by-products, and vegetable proteins used in the production of dog and cat diets. Poult Sci 98:1371-1378

Dozier WA III, Dale NM, Dove CR (2003) Nutrient composition of feed-grade and pet-food-grade poultry by-product meal. J Appl Poult Res 12:526-530

Dumas A, Raggi T, Barkhouse J et al (2018) The oil fraction and partially defatted meal of black soldier fly larvae (Hermetia illucens) a ffect differently growth performance, feed efficiency, nutrient deposition, blood glucose and lipid digestibility of rainbow trout (Oncorhynchus mykiss). Aquaculture 492:24-34

Dust JM, Grieshop CM, Parsons CM et al (2005) Chemical composition, protein quality, palatability, and digestibility of alternative protein sources for dogs. J Anim Sci 83:2414-2422

Fan XX, Li S, Wu ZL et al (2019) Glycine supplementation to breastfed piglets attenuates postweaning jejunal epithelial apoptosis: a functional role of CHOP signaling. Amino Acids 51:463-473
FAO (2018) The State of World Fisheries and Aquaculture 2018 Meeting the sustainable development goals, Rome.

Frikha M, Mohiti-Asli M, Chetrit C et al (2014) Hydrolyzed porcine mucosa in broiler diets: effects on growth performance, nutrient retention, and histomorphology of the small intestine. Poult Sci 93:400-411

Fu WJ, Stromberg AJ, Viele K et al (2010) Statistics and bioinformatics in nutritional sciences: analysis of complex data in the era of systems biology. J Nutr Biochem 21:561-572

Gorissen SHM, Crombag JJR, Senden JMG et al (2018) Protein content and amino acid composition of commercially available plantbased protein isolates. Amino Acids 50:1685-1695

Hou YQ, Wu G (2017) Nutritionally nonessential amino acids: a misnomer in nutritional sciences. Adv Nutr 8:137-139

Hou YQ, Wu G (2018a) Nutritionally essential amino acids. Adv Nutr 9:849-851

Hou YQ, Wu G (2018b) L-Glutamate nutrition and metabolism in swine. Amino Acids 50:1497-1510

Hou YQ, Yin YL, Wu G (2015a) Dietary essentiality of "nutritionally nonessential amino acids" for animals and humans. Exp Biol Med 240:997-1007

Hou YQ, Jia SC, Nawaratna G et al (2015b) Analysis of L-homoarginine in biological samples by HPLC involving pre-column derivatization with $o$-phthalaldehyde and $N$-acetyl-L-cysteine. Amino Acids 47:2005-2014

Hou YQ, Wu ZL, Dai ZL et al (2017) Protein hydrolysates in animal nutrition: Industrial production, bioactive peptides, and functional significance. J Anim Sci Biotechnol 8:24

Hou YQ, He WL, Hu SD, Wu G (2019) Composition of polyamines and amino acids in plant-source foods for human consumption. Amino Acids 51:1153-1165

Friedman M, Brandon DL (2001) Nutritional and health benefits of soy proteins. J Agric Food Chem 49:1069-1086

Jamdar SN, Harikumar P (2008) A rapid autolytic method for the preparation of protein hydrolysate from poultry viscera. Bioresource Technol 99:6934-6940

Jobgen WS, Ford SP, Jobgen SC et al (2008) Baggs ewes adapt to maternal undernutrition and maintain conceptus growth by maintaining fetal plasma concentrations of amino acids. J Anim Sci $86: 820-826$

Jongema Y (2012) List of edible insects of the world. https://www.ent. wur.nl/UK/Edible+insects/Worldwide+species+list/

Kai M, Miyazaki T, Yamaguchi M et al (1983) High performance liquid chromatography of guanidino compounds using benzoin as pre-column derivatization reagent. J Chromatogr 268:417-424

Kawasaki K, Hashimoto Y, Hori A et al (2019) Evaluation of black soldier fly (Hermetia illucens) larvae and pre-pupae raised on household organic waste, as potential ingredients for poultry feed. Animals 9:98

Kerr BJ, Jha R, Urriola PE, Shurson GC (2017) Nutrient composition, digestible and metabolizable energy content, and prediction of energy for animal protein byproducts in finishing pig diets. J Anim Sci 95:2614-2626

Kim JH, Chae BJ, Kim YG (2000) Effects of replacing spray dried plasma protein with spray dried porcine intestine hydrolysate on ileal digestibility of amino acids and growth performance in earlyweaned pigs. Asian-Aus J Anim Sci 13:1738-1742

Klemesrud MJ, Klopfenstein TJ, Lewis AJ et al (1997) Limiting amino acids in meat and bone and poultry by-product meals. J Anim Sci 75:3294-3300

Koyande AK, Chew KW, Rambabu K et al (2019) Microalgae: A potential alternative to health supplementation for humans. Food Sci Hum Wellness 8:16-24

Lamprecht W, Stein P (1965) Creatine phosphate: In: Bergmeyer H-U (eds) Methods of enzymatic analysis. Academic Press, New York 
Le Floc'h N, Wessels A, Corrent E, et al (2018) The relevance of functional amino acids to support the health of growing pigs. Anim Feed Sci Technol 245:104-116

Lei XJ, Kim TH, Park JH, Kim IH (2019) Evaluation of supplementation of defatted black soldier fly (Hermetia illucens) larvae meal in beagle dogs. Ann Anim Sci 19:767-777

Lenis YY, Elmetwally MA, Tang W et al (2018) Functional roles of agmatinase during the peri-implantation period of pregnancy in sheep. Amino Acids 50:293-308

Li P, Wu G (2018) Roles of dietary glycine, proline and hydroxyproline in collagen synthesis and animal growth. Amino Acids 50:29-38

Li P, Yin YL, Li DLG et al (2007) Amino acids and immune function. Br J Nutr. 98:237-252

Li P, Mai KS, Trushenski J, Wu G (2009) New developments in fish amino acid nutrition: towards functional and environmentally oriented aquafeeds. Amino Acids 37:43-53

Li XL, Rezaei R, Li P, Wu G (2011) Composition of amino acids in feed ingredients for animal diets. Amino Acids 40:1159-1168

Lieherman HR (1994) Tyrosine and stress: human and animal studies. In: Marriott BM (ed) Food components to enhance performance, an evaluation of potential performance-enhancing food components for operational rations. National Academy Press, Washington DC, Institute of Medicine, pp 277-299

Liu YZ, Gen H, Wang Q et al. (2014) Kangsen Mai, Wei Xu, and Huihui Zhou. Hydroxyproline supplementation on the performances of high plant protein source based diets in turbot (Scophthalmus maximus L.) Aquaculture 433:476-480

Liu N, Dai ZL, Jia H et al (2019) Maternal L-proline supplementation during gestation alters amino acid and polyamine metabolism in the first generation female offspring of C57BL/6J mice. Amino Acids 51:805-811

MacEvilly C (2000) Bugs in the system. Nutr. Bulletin 25:267-268

Maddock RJ, Bidner BS, Carr SN et al (2002) Creatine monohydrate supplementation and the quality of fresh pork in normal and halothane carrier pigs. J Anim Sci 80:997-1004

Martinis P, Grancara S, Kanamori Y et al. (2019) Involvement of the biogenic active amine agmatine in mitochondrial membrane permeabilization and release of pro-apoptotic factors. Amino Acids 521:161-169

Meeker DL, Hamilton CR (2006) An overview of the rendering industry. In: Meeker DL (ed) Essential rendering. Kirby Lithographic Company Inc, Arlington, pp 1-16

Meléndez-Hevia E, De Paz-Lugo P, Cornish-Bowden A, Cárdenas ML (2009) A weak link in metabolism: the metabolic capacity for glycine biosynthesis does not satisfy the need for collagen synthesis. J Biosci 34:853-872

Myers AJ, Goodband RD, Tokach MD et al (2014) The effects of porcine intestinal mucosa protein sources on nursery pig growth performance. J Anim Sci 92:783-792

Murray SM, Patil AR, Fahey GC Jr et al (1997) Raw and rendered animal by-products as ingredients in dog diets. J Anim Sci 75:2497-2505

Ng RH, Marshall FD (1976) Subcellular distribution and some properties of homocarnosine-carnosine synthetase from chick red blood cells. Comp Biochem Physiol B 54:523-525

Norberg SE, Dilger RN, Dong H et al (2004) Utilization of energy and amino acids of spray-dried egg, plasma protein, and soybean meal by ducks. Poultry Sci 83:939-945

Provenzano B, Lentini A, Tatti R et al. (2019) Evaluation of polyamines as marker of melanoma cell proliferation and differentiation by an improved high-performance liquid chromatographic method. Amino Acids 51:1623-1631

Ravindran V, Hew LI, Ravindran G, Bryden WL (2005) Apparent ileal digestibility of amino acids in dietary ingredients for broiler chickens. Anim Sci 81:85-97
Renna M, Schiavone A, F. Gai F (2017) Evaluation of the suitability of a partially defatted black soldier fly (Hermetia illucens L.) larvae meal as ingredient for rainbow trout (Oncorhynchus mykiss Walbaum) diets. J Anim Sci Biotechnol 8:57

Roos N (2018) Insects and human nutrition. In: Halloran A, Flore R, Vantomme P, Roos N (eds) Edible insects in sustainable food systems. Springer, Cham

Rumpold BA, Schlüter OK (2013) Potential and challenges of insects as an innovative source for food and feed production". Innovative Food Sci Emerging Technol 17:1-11

Shumo M, Osuga IM, Khamis FM et al (2019) The nutritive value of black soldier fly larvae reared on common organic waste streams in Kenya. Sci Rep 9:10110

Singh P, Kumar R, Sabapathy SN et al (2008) Functional and edible uses of soy protein products. Comprehensive Rev Food Sci Food Safety. 7:14-28

Spranghers T, Ottoboni M, Klootwijk C et al (2017) Nutritional composition of black soldier fly (Hermetiaillucens) prepupae reared on different organic waste substrates. J Sci Food Agric 97:2594-2600

Sulabo RC, Mathai JK, Usry JL et al (2013) Nutritional value of dried fermentation biomass, hydrolyzed porcine intestinal mucosa products, and fish meal fed to weanling pigs. J Anim Sci 91:2802-2811

Suryawan A, Rudar M, Fiorotto ML, Davis TA (2020) Differential regulation of mTORC 1 activation by leucine and $\beta$-hydroxy- $\beta$ methylbutyrate in skeletal muscle of neonatal pigs. J Appl Physiol. 128:286-295

Turchini GM, Trushenski JT, Glencross BD (2019) Thoughts for the future of aquaculture nutrition: Realigning perspectives to reflect contemporary issues related to judicious use of marine resources in aquafeeds. North Am J Aquaculture 81:13-39

Vallet JL, Miles JR, Rempel LA (2013) Effect of creatine supplementation during the last week of gestation on birth intervals, stillbirth, and preweaning mortality in pigs. J Anim Sci 91:2122-2132

Vavricka CJ, Han Q, Mehere P et al (2014) Tyrosine metabolic enzymes from insects and mammals: a comparative perspective. Insect Sci 21:13-19

Wallimann T, Tokarska-Schlattner M, Schlattner U (2011) The creatine kinase system and pleiotropic effects of creatine. Amino Acids 40:1271-1296

Wells ML, Potin P, Craigie JS et al (2017) Algae as nutritional and functional food sources: revisiting our understanding. J Appl Phycol 29:949-982

Wolff J, Horisaka K, Fales HM (1968) On the structure of ophidine. Biochemistry 7:2455-2457

Wu G (2013) Amino acids: biochemistry and nutrition. CRC Press, Boca Raton

Wu G (2018) Principles of animal nutrition. CRC Press, Boca Raton

Wu G, Meininger CJ (2008) Analysis of citrulline, arginine, and methylarginines using high-performance liquid chromatography. Methods Enzymol 440:177-189

Wu G, Bazer FW, Burghardt RC et al (2011) Proline and hydroxyproline metabolism: implications for animal and human nutrition. Amino Acids 40:1053-1063

Wu G, Bazer FW, Dai ZL et al (2014) Amino acid nutrition in animals: protein synthesis and beyond. Annu Rev Anim Biosci 2:387-417

Wu G, Cross HR, Gehring KB et al (2016a) Composition of free and peptide-bound amino acids in beef chuck, loin, and round cuts. J Anim Sci 94:2603-2613

Wu ZL, Hou YQ, Hu SD et al (2016b) Catabolism and safety of supplemental L-arginine in animals. Amino Acids 48:1541-1552

Wu G, Bazer FW, Johnson GA, Hou YQ (2018) Arginine nutrition and metabolism in growing, gestating and lactating swine. J Anim Sci 96:5035-5051

Wu ZL, Hou YQ, Dai ZL et al (2019) Metabolism, nutrition and redox signaling of hydroxyproline. Antioxid Redox Signal 30:674-682 
Wurtman RJ, Hefti F, Melamed E (1981) Precursor control of neurotransmitter synthesis. Pharmacol Rev 32:315-335

Yang ZY, Liao SF (2019) Physiological effects of dietary amino acids on gut health and functions of swine. Front Vet Sci 6:169

Yi D, Li BC, Hou YQ et al (2018) Dietary supplementation with an amino acid blend enhances intestinal function in piglets. Amino Acids 50:1089-1100

Young JF, Bertram HC, Theil PK et al (2007) In vitro and in vivo studies of creatine monohydrate supplementation to Duroc and Landrace pigs. Meat Sci 76:342-351

Zhang Y, Chen DW, Yu B et al (2015) Spray-dried chicken plasma improves intestinal digestive function and regulates intestinal selected microflora in weaning piglets. J Anim Sci 93:2967-2976
Zhang JM, He WL, Yi D et al (2019) Regulation of protein synthesis in porcine mammary epithelial cells by L-valine. Amino Acids $51: 717-726$

Publisher's Note Springer Nature remains neutral with regard to jurisdictional claims in published maps and institutional affiliations. 